\title{
MicroRNAs in Uteroplacental Vascular Dysfunction
}

\author{
Xiang-Qun $\mathrm{Hu} *$ (1) and Lubo Zhang * \\ Lawrence D. Longo MD Center for Perinatal Biology, Division of Pharmacology, Department of Basic Sciences, \\ Loma Linda University School of Medicine, Loma Linda, CA 92350, USA \\ * Correspondence: xhu@llu.edu (X.-Q.H.); lzhang@llu.edu (L.Z.)
}

Received: 3 October 2019; Accepted: 27 October 2019; Published: 29 October 2019

\begin{abstract}
Pregnancy complications of preeclampsia and intrauterine growth restriction (IUGR) are major causes of maternal and perinatal/neonatal morbidity and mortality. Although their etiologies remain elusive, it is generally accepted that they are secondary to placental insufficiency conferred by both failure in spiral artery remodeling and uteroplacental vascular malfunction. MicroRNAs (miRNAs) are small no-coding RNA molecules that regulate gene expression at the post-transcriptional level. Increasing evidence suggests that miRNAs participate in virtually all biological processes and are involved in numerous human diseases. Differentially expressed miRNAs in the placenta are typical features of both preeclampsia and IUGR. Dysregulated miRNAs target genes of various signaling pathways in uteroplacental tissues, contributing to the development of both complications. In this review, we provide an overview of how aberrant miRNA expression in preeclampsia and IUGR impacts the expression of genes involved in trophoblast invasion and uteroplacental vascular adaptation.
\end{abstract}

Keywords: miRNA; trophoblast invasion; uterine vascular adaptation; preeclampsia; intrauterine growth restriction

\section{Introduction}

MicroRNAs (miRNAs) are small non-coding RNAs ( 22 nucleotides in length) expressed in plants, invertebrates and vertebrates. These molecules generally regulate gene expression through sequence-specific base pairing with target mRNAs, leading to transcript degradation and translational repression. To date, more than two thousand human miRNAs have been identified [1]. Over $60 \%$ human protein coding-genes are targeted by miRNAs [2]. Notably, a single miRNA can target multiple mRNAs and a specific mRNA can also harbor complimentary binding sites in the $3^{\prime}$ untranslated region ( $3^{\prime}$-UTR) for various miRNAs. Although miRNA research is still in its infancy, the physiological and pathophysiological roles of miRNAs are emerging rapidly. It is clear that miRNAs are involved in virtually every biological process, including cell development, metabolism, proliferation, differentiation, motility and apoptosis. Moreover, the dysregulation of miRNAs is linked with various human diseases such as but not limited to cancer, neurological diseases, and cardiovascular disease [2].

Preeclampsia is characterized by de novo maternal hypertension $(>140 / 90 \mathrm{~mm} \mathrm{Hg}$ ) after 20 weeks of gestation, accompanied by proteinuria or other maternal organ damage or uteroplacental dysfunction [3,4]. Intrauterine growth restriction (IUGR; also known as fetal growth restriction, FGR), characterized as failure of the fetus to achieve his/her genetically determined growth potential, is defined as birth weight less than the 10th percentile [5]. Preeclampsia and IUGR are the most common complications of pregnancy, affecting 3-10\% of pregnancies worldwide and being primary causes of maternal and/or fetal/neonatal mortality and morbidity [6-8]. Early-onset, but not late-onset, preeclampsia is often associated with increased incidence of IUGR [6,9]. Currently, there is no effective treatment for both complications. Besides their impacts on maternal health and fetal development, 
these pregnancy disorders also confer an increased risk of cardiovascular diseases later in life $[8,10,11]$. Moreover, IUGR is often associated with increased incidence of metabolic diseases in adulthood [12]. Etiologies of preeclampsia and IUGR remain unclear. However, the placental dysfunction is known to be essential for the development of preeclampsia and IUGR. The most effective cure for preeclampsia is the delivery/removal of the placenta. The dysfunction of uteroplacental vessels and failure to transform spiral arteries result in reduced placental perfusion, leading to placental insufficiency (uteroplacental vascular insufficiency). Both complications are believed to start from placental insufficiency but with different clinical manifestations $[9,13,14]$.

Despite being a temporary organ developed in the uterus during pregnancy, the placenta expresses many miRNAs including placenta-specific miRNAs. These miRNAs play important roles in placental development and uteroplacental circulation adaptation [15-17]. Not surprisingly, dysregulated expression of uteroplacental miRNAs has been demonstrated in both preeclampsia and IUGR, implicating their potential roles in the pathogenesis of these complications $[15,18,19]$. In this review, we primarily focus on the dysregulation of trophoblast invasion and uteroplacental vascular maladaptation conferred by aberrantly expressed miRNAs in preeclampsia and IUGR.

\section{MiRNA Expression Patterns in Uteroplacental Tissues}

\subsection{Biogenesis of miRNAs}

In human and animal cells, mature miRNAs are produced through a series of enzymatic reactions in the nucleus and cytoplasm. In the nucleus, a miRNA gene is initially transcribed by RNA polymerase II to produce a large miRNA termed primary miRNA (pri-miRNA) in which the mature miRNA sequence is embedded. The pri-miRNA is then processed by a microprocessor complex containing the RNase III enzyme Drosha and its cofactor DiGeorge syndrome critical region 8 (DGCR8). The pri-miRNA is recognized by DGCR8 and cleaved by Drosha. The enzymatic action produces a pre-miRNA with $\sim 70$ nucleotides in length. Subsequently, the pre-miRNA is transported to the cytoplasm by exportin-5 with Ran-GTP being a cofactor [20]. Once in the cytoplasm, the pre-miRNA is further processed by Dicer, a ribonuclease III (RNase III), to generate a double-stranded miRNA of $\sim 22$ nucleotides.

\subsection{MiRNA on Gene Expression}

The miRNA generated by Dicer is a complementary duplex of miRNA:miRNA*. Whereas miRNA denotes the guide strand (mature miRNA), miRNA* symbolizes the passenger strand. After unwinding by helicases, the miRNA* is degraded, whereas the mature miRNA is loaded onto Argonaute (AGO) protein family (AGO1-4 in human) to form an RNA-induced silencing complex (RISC). Since miRBase release 17 , the symbolism miRNA:miRNA* has been replaced with " $5 p / 3 p$ " strand annotation [21]. For a fraction of miRNAs, either of both strands could be loaded to AGOs. The miRNA guides the RISC to its target mRNA by base paring with the complementary sequence located mainly in the $3^{\prime}$-UTR of mRNAs. The 'seed' sequence located between nucleotides 2 and 7 of the $5^{\prime}$ end of the miRNA is crucial for target site recognition. Consequently, the binding of the RISC to the target mRNA induces transcript degradation and/or translational repression [22,23]. The base-paring between miRNA and mRNA is usually imperfect. Each miRNA may have hundreds of potential mRNA targets, and a given target may also harbor multiple binding sequences for different miRNAs, resulting in a complex regulatory network. Interestingly, some miRNAs are found to activate mRNA translation, although the underlying mechanisms are not fully understood [24,25].

\subsection{Placental miRNAs in Normal Pregnancy}

The human placenta expresses numerous miRNAs to various degree and trophoblasts constitute the major source of placental miRNAs [26-28]. Over 600 miRNAs have been identified in normal term human placenta using high-throughput approaches such as miRNA array and next-generation 
sequencing $[29,30]$. Similarly, 762 miRNAs are also detected in trophoblasts isolated from the placenta and approximately half of them are notably expressed [27]. Among these miRNAs, chromosome 19 miRNA cluster (C19MC), chromosome 14 miRNA cluster (C14MC) and miR-371-3 cluster are exclusively or preferentially expressed in the human placenta [19]. C19MC harbors 46 genes encoding 58 miRNAs, while C14MC and miR-371-3 cluster consist of 52 and 3 members, respectively. When miRNA expression patterns were examined in placentas or isolated primary trophoblasts from first and third trimester placentas, it appeared that the expression of many placental miRNAs varied with gestational stages. A study using TaqMan array showed that the expression of C19MC increased, whereas the expression of C14MC occurred conversely in trophoblasts as pregnancy advanced [27]. Interestingly, Gu et al. demonstrated that 191 miRNAs were differentially expressed between first and third trimester placentas with 97 downregulated and 94 upregulated in the third trimester using GeneChip miRNA 2.0 array [31]. Further analysis revealed that significant portions of C14MC and C19MC miRNAs as well as the miR-17-92 cluster were downregulated and several members of the let-7 family were upregulated in the third trimester placenta. A subsequent study using miRCURY LNA $^{\mathrm{TM}}$ microRNA array showed differential expression of 58 miRNAs between first and third trimester placentas with 41 miRNAs upregulated in term placentas [32]. Among the differentially expressed miRNAs, only 13 of them (miR-10a, miR-29a, miR-29b, miR-29c, miR-101, miR-125b, miR-143, miR-221, miR-377, miR-526b, let-7a, let-7d, and let-7f) were upregulated, whereas miR-675 was the only miRNA downregulated in the third trimester in these two studies. The discrepancies among those studies may result from the lack of standardized protocols, sensitivities of miRNA detection assays, sampling sites of the placenta, gestational ages when samples collected, cell homogeneity/heterogeneity and race/ethnicity, etc. There are also temporal changes for other miRNAs in the placenta. For example, the expression of miR-378a-5p in the placenta was lower in the third trimester than in the first and second trimesters [33]. In contrast, miR-411 and miR-376c levels in the placenta increased progressively over the gestational stages $[34,35]$. The temporal expression pattern of given miRNAs in the placenta suggest that they may possess stage-specific functions and could play an important role in the placental development.

\subsection{Placental miRNAs in Compromised Pregnancies}

The approaches of miRNA array, high-throughput screening and next generation sequencing have been frequently applied to examine expression profiles of miRNAs in placentas of normal and complicated pregnancies $[29,30,36-47]$. Similar but limited studies using these approaches were also used to profile miRNA expression in IUGR placentas [48-50]. These investigations revealed distinct sets of differentially expressed miRNAs (DEMs) between normal and preeclamptic/IUGR placentas. For example, miRNA profiling conducted by Hromadnikova et al. revealed that 11 (miR-515-5p, miR-517-5p, miR-518b, miR-518f-5p, miR-519a, miR-519d, miR-520a-5p, miR-520h, miR-524-5p, miR-525, and miR-526a) and 6 (miR-517-5p, miR-518f-5p, miR-519a, miR-519d, miR-520a-5p, and miR-525) miRNAs of C19MC in preeclamptic and IUGR placentas were downregulated, respectively, compared to placentas of normal pregnancy [51]. Xu et al. [43] observed that 5 of 6 members in miR-17-92 cluster (miR-17, miR-18a, miR-19a, miR-19b, and miR-20a) were downregulated in severe preeclamptic placentas. By examining cardiovascular and cerebrovascular disease associated microRNAs, Hromadnikova et al. [52] demonstrated that placentas from preeclampsia and IUGR requiring termination of gestation before 34 weeks of gestation exhibited downregulation of miR-26a-5p, miR-103a-3p and miR-145-5p and upregulation of miR-499a-5p. They also revealed specific downregulation of placental miR-122-5p, miR-125b-5p, and miR-195-5p in IUGR requiring the delivery before 34 weeks of gestation. Distinct miRNA profiles suggest a role for miRNAs in the pathological processes of preeclampsia and IUGR. Intriguingly, results from these studies varied significantly and sometimes were contradictory. Data pooled from 14 independent studies on miRNA expression in preeclamptic placentas revealed that only a relatively small fraction of DEMs (55 out of 304 miRNAs) changed in the same directions in at least two different studies [29,30,36-47] (Figure 1). 


\begin{tabular}{ll}
\hline miR-142-5p (2) & let-7c (2) \\
miR-152 (2) & miR-1 (2) \\
miR-16 (2) & miR-101 (2) \\
miR-181a (4) & miR-126 (2) \\
miR-181b (2) & miR-126-5p (2) \\
miR-182 (2) & miR-139-5p (3) \\
miR-193b (4) & miR-150 (2) \\
miR-20a (2) & miR-18a (2) \\
miR-20b (2) & miR-192 (2) \\
miR-210 (9) & miR-195 (2) \\
miR-25 (2) & miR-200c (3) \\
miR-26b (2)* & miR-21 (2) \\
miR-296-3p (2) & miR-218 (3) \\
miR-424 (2) & miR-223 (5) \\
miR-451 (2) & miR-224 (3) \\
miR-455-5p (2) & miR-26b (2)* \\
miR-483-5p (2) & miR-32 (2) \\
miR-518b (3) & miR-34c-5p (2) \\
miR-519e-5p (2) & miR-363 (3) \\
miR-520a-3p (3) & miR-377 (2) \\
miR-520g (2) & miR-379 (2) \\
miR-574-5p (2) & miR-411 (2) \\
miR-638 (2) & miR-489 (2) \\
& miR-519c-3p (2) \\
& miR-520b (2) \\
*Both upregulation & miR-520c-3p (2) \\
and downregulation & miR-551b (2) \\
of miR-26b appeared & miR-625 (2) \\
in two studies. & miR-744 (2) \\
& \\
& \\
&
\end{tabular}

Figure 1. Common members of differentially expressed 304 microRNAs (miRNAs) in preeclamptic placentas detected with high throughout approaches that appeared in at least 2 out of 14 independent studies (see text for detail). MiRNAs in the red box were upregulated and those in the green box were downregulated. Number in parentheses denotes number of studies.

The possible causes have been discussed above. Although miRNA profiling approaches are prominent tools to identify DEMs in healthy and pathological conditions, they (especially miRNA array) have their drawbacks such as lower specificity and less quantitative [53,54]. Quantitative reverse transcription polymerase chain reaction (qRT-PCR) is a gold standard technique for accurately quantifying gene expression and is frequently used to validate findings from gene expression profiling. A variety of miRNAs, detected by qRT-PCR, have been found to be aberrantly expressed in preeclamptic and IUGR placentas. A short list of them is presented in Table 1. Interestingly, miR-210 appears to be the most commonly dysregulated miRNA in preeclamptic and IUGR placentas (Figure 1, Table 1). To date, there has been only one study explored miRNA expression in uterine arteries of high-altitude pregnant sheep model which displays mixed features of both early-onset and late-onset preeclampsia. In this study, Hu et al. revealed that miR-210 in uterine arteries of high altitude pregnant sheep was elevated compared to low altitude pregnant animals [55]. 
Table 1. Aberrant expression of placental miRNAs detected with qRT-PCR in preeclampsia and intrauterine growth restriction (IUGR).

\begin{tabular}{|c|c|c|c|}
\hline \multicolumn{4}{|c|}{ Preeclampsia } \\
\hline \multicolumn{2}{|c|}{ Upregulation } & \multicolumn{2}{|c|}{ Downregulation } \\
\hline miRNA & Reference(s) & miRNA & Reference(s) \\
\hline let-7b & [56] & let-7c-5p & [57] \\
\hline let-7d & [58] & miR-1 & [39] \\
\hline miR-16 & [37] & miR-18a & {$[38,43]$} \\
\hline miR-17 & [30] & $\operatorname{miR}-19 a-3 p$ & [59] \\
\hline miR-17-3p & [43] & miR-19b & [43] \\
\hline $\operatorname{miR}-19 b$ & [60] & miR-21 & [61] \\
\hline miR-20a & {$[30,62]$} & $\operatorname{miR}-27 a-5 p$ & [63] \\
\hline $\operatorname{miR}-20 \mathrm{~b}$ & [30] & $\operatorname{miR}-34 c-5 p$ & [39] \\
\hline $\operatorname{miR}-25$ & [42] & miR-101 & [64] \\
\hline miR-26b & {$[37,42]$} & miR-126 & {$[65,66]$} \\
\hline miR-29b & {$[37,67]$} & miR-127-3p & {$[57]$} \\
\hline miR-31-5p & [63] & miR-133b & [56] \\
\hline miR-30a-3p & {$[43,68]$} & miR-135b-5p & [63] \\
\hline miR-34a & {$[69,70]$} & $\operatorname{miR}-136-3 p$ & [63] \\
\hline miR-34a-5p & [71] & miR-139-5p & [39] \\
\hline miR-92b & [42] & miR-144 & [72] \\
\hline miR-104 & [56] & miR-144-3p & [73] \\
\hline miR-106a & {$[60]$} & $\operatorname{miR}-149$ & {$[74]$} \\
\hline miR-124-5p & [46] & miR-149-5p & [75] \\
\hline miR-125b-1-3p & [76] & miR-194 & [74] \\
\hline miR-128a & [56] & miR-195 & [43] \\
\hline miR-137 & [77] & miR-218 & [43] \\
\hline miR-141 & [78] & $\operatorname{miR}-218-5 p$ & [79] \\
\hline $\operatorname{miR}-142-3 p$ & {$[77,80]$} & $\operatorname{miR}-221-3 p$ & [81] \\
\hline miR-148a-3p & [63] & $\operatorname{miR}-223$ & {$[43,82]$} \\
\hline miR-151 & [43] & $\operatorname{miR}-224$ & [82] \\
\hline miR-152 & [38] & miR-325 & [83] \\
\hline miR-154-3p & [36] & miR-328 & [39] \\
\hline miR-155 & {$[36,84]$} & miR-335 & [45] \\
\hline miR-181a & {$[37,45]$} & $\operatorname{miR}-346$ & [85] \\
\hline miR-181a-5p & {$[84,86]$} & miR-363 & {$[38,45]$} \\
\hline miR-182 & {$[36,45]$} & miR-365a-3p & [63] \\
\hline $\operatorname{miR}-182-3 p$ & {$[36,56]$} & miR-376c & {$[34,35]$} \\
\hline miR-182-5p & [87] & miR-377 & {$[38]$} \\
\hline miR-183 & [36] & miR-378a-5p & [33] \\
\hline miR-193b & {$[43,63]$} & $\operatorname{miR}-379$ & [43] \\
\hline miR-193b-3p & [63] & $\operatorname{miR}-411$ & {$[35,38,43]$} \\
\hline miR-195 & {$[37,88]$} & miR-454 & {$[89,90]$} \\
\hline miR-197 & [42] & miR455-3p & [91] \\
\hline miR-200b & [36] & $\operatorname{miR} 455-5 p$ & [91] \\
\hline miR-202-3p & [92] & miR-515-5p & {$[91,93]$} \\
\hline miR-203 & {$[94]$} & $\operatorname{miR}-517-5 p$ & [51] \\
\hline miR-210 & {$[36,38,39,43,63,95-100]$} & $\operatorname{miR}-518 f-5 p$ & [51] \\
\hline $\operatorname{miR}-218$ & [101] & miR-519a & [51] \\
\hline miR-222 & [37] & miR-519a-3p & [57] \\
\hline miR-296-3p & [42] & miR-519d & [51] \\
\hline miR-296-5p & [42] & miR-520a-5p & {$[51,63]$} \\
\hline miR-299 & [102] & miR-520h & [51] \\
\hline miR-320a & [103] & $\operatorname{miR}-524-5 p$ & [51] \\
\hline miR-335 & {$[37,44]$} & miR-525 & [51] \\
\hline $\operatorname{miR}-342-3 p$ & [42] & miR-526a & [51] \\
\hline $\operatorname{miR}-362-3 p$ & [104] & miR-532-5p & [57] \\
\hline $\operatorname{miR}-423-5 p$ & [57] & miR-539-5p & [57] \\
\hline
\end{tabular}


Table 1. Cont.

\begin{tabular}{|c|c|c|c|}
\hline \multicolumn{4}{|c|}{ Preeclampsia } \\
\hline \multicolumn{2}{|c|}{ Upregulation } & \multicolumn{2}{|c|}{ Downregulation } \\
\hline miRNA & Reference(s) & miRNA & Reference(s) \\
\hline $\operatorname{miR}-424$ & [45] & $\operatorname{miR}-542-3 p$ & [38] \\
\hline miR-431 & {$[46,105]$} & miR-544 & [46] \\
\hline miR-517-5p & [106] & miR-584 & [39] \\
\hline $\mathrm{miR}-517 \mathrm{a} / \mathrm{b}$ & [107] & miR-629-5p & [57] \\
\hline miR-517c & [107] & miR-652-3p & [108] \\
\hline miR-518a-5p & [46] & miR-675 & [109] \\
\hline $\operatorname{miR}-519 d-3 p$ & [110] & miR-1301 & [82] \\
\hline miR-520g & [111] & & \\
\hline $\operatorname{miR}-524$ & [43] & & \\
\hline $\operatorname{miR}-584$ & {$[44]$} & & \\
\hline
\end{tabular}

IUGA

\begin{tabular}{|c|c|c|c|}
\hline \multicolumn{2}{|c|}{ Upregulation } & \multicolumn{2}{|c|}{ Downregulation } \\
\hline miRNA & Reference(s) & miRNA & Reference(s) \\
\hline miR-10b & [49] & miR-16-5p & [52] \\
\hline miR-141 & [112] & $\operatorname{miR}-21$ & {$[113,114]$} \\
\hline miR-193b-3p & [47] & miR-26a-5p & [52] \\
\hline miR-193b-5p & [47] & miR-100-5p & [52] \\
\hline miR-210 & [95] & miR-103a-3p & [52] \\
\hline $\operatorname{miR}-210-3 p$ & {$[47,115]$} & miR-122-5p & [52] \\
\hline miR-221-3p & [47] & miR-125b-5p & [52] \\
\hline miR-342-3p & [47] & miR-126-3p & [52] \\
\hline miR-363 & [49] & miR-143-3p & [52] \\
\hline miR-365a/b-3p & [47] & miR-145-5p & [52] \\
\hline miR-424 & [116] & miR-149 & [74] \\
\hline miR-499a-5p & [52] & miR-199a-5p & [52] \\
\hline miR-519a & {$[51,117]$} & miR-346 & [85] \\
\hline \multirow[t]{11}{*}{ miR-574-3p } & [47] & miR-515-5p & [48] \\
\hline & & miR-516b & [48] \\
\hline & & $\operatorname{miR}-517-5 p$ & [51] \\
\hline & & miR-518b & {$[48,117]$} \\
\hline & & miR-518f-5p & [51] \\
\hline & & miR-519d & {$[48,51]$} \\
\hline & & miR-520a-5p & {$[51]$} \\
\hline & & miR-520h & [48] \\
\hline & & miR-525 & [51] \\
\hline & & miR-526b & {$[48]$} \\
\hline & & $\operatorname{miR}-1323$ & [48] \\
\hline
\end{tabular}

\section{MiRNAs and Uteroplacental Circulation Adaptation under Physiological and Pathophysiological Conditions}

The demand of the growing fetus in utero for nutrients and oxygen requires adequate perfusion of the placenta. To accommodate this requirement, maternal cardiovascular system undergoes significant changes as evidenced by $\sim 50 \%$ increase in blood volume and cardiac output and a fall in systemic vascular resistance [118]. Dramatic changes also occur locally. For example, uterine blood flow in human and sheep rises from $\sim 3 \%$ of cardiac output in the non-pregnant state to $\sim 20 \%$ at term gestation, corresponding to $\sim 20-50$-fold increases in uterine blood flow volume [118]. The increase in uterine blood flow is owing to markedly reduced uterine vascular resistance, conferred by structural and functional changes of uterine arteries in pregnancy. 


\subsection{Structural Adaptation of Uterine Arteries in Normal Pregnancy}

Structural adaptation of uterine arteries during pregnancy includes the outward expansive growth of large uterine arteries and remodeling of spiral arteries. One prominent structural change of main uterine, arcuate and radial arteries during pregnancy is the increase in arterial caliber. The diameter of these large arteries increases 2-3-fold in human and various animals [119-126]. These changes are believed to be the results of vascular smooth muscle hypertrophy and hyperplasia stimulated by estrogen [127]. However, the increase in arterial caliber is without changes in the thickness of the vessel wall $[119,122]$. The increased uterine size due to fetal growth could also passively increase the length of uterine arteries.

The remodeling of spiral arteries occurs in the first half of gestation, fulfilled by extravillous trophoblasts (EVTs) arisen from anchoring villi. The coordinated work by two distinct EVT populations, interstitial EVTs and endovascular EVTs, accomplishes the remodeling process [128,129]. Interstitial EVTs migrate through the uterine stroma, whereas endovascular EVTs migrate in a retrograde manner through the lumen of spiral arteries. The invasion of interstitial EVTs through the uterine interstitium allows them to reach and penetrate the arterial wall, participating in the destruction of arterial media directly or priming vascular smooth muscle cells to be destructed by endovascular EVTs [130,131]. As endovascular EVTs migrate across the inner wall of spiral arteries, they induce apoptosis of endothelial cells and vascular smooth muscle cells [132-134], leaving trophoblasts to form the new lining of the lumen and an inert, amorphous fibrinoid material to replace the tunica media. Interestingly, these trophoblasts adopt an endothelial-like phenotype, leading to an apparent re-endothelialization of the vessels [135]. However, it is also suggested that endovascular EVTs promote the migration of vascular smooth muscle cells away from the vessel, but not myocyte apoptosis [136]. Consequently, the vessels become dilated and are converted into flaccid conduits. The mouth of spiral arteries increases from $\sim 200 \mu \mathrm{m}$ in the non-pregnant state up to 2-3 $\mathrm{mm}$ at term of gestation [137]. In addition, the deficit of vascular smooth muscle cells following the remodeling results in loss of responsiveness of spiral arteries to vasoconstrictors.

\subsection{Functional Adaptation of Uterine Arteries in Normal Pregnancy}

Profound functional adaptations also occur in uterine arteries during gestation. Estrogen appears to be a major initiator of these changes mainly through interacting with its receptors [138,139]. In humans, starting from approximately week 9 of gestation, the placental syncytiotrophoblast becomes the predominant source of estrogen during pregnancy [140]. The circulating level of $17 \beta$-estradiol $\left(E_{2} \beta\right)$ progressively increases over the duration of pregnancy [141]. Coincidentally, uterine blood flow also increases [123,125,142]. A causative role of estrogen and its receptors in pregnancy-induced increase in uterine blood flow was established in a sheep model based on the observations that: 1) a local infusion of an estrogen receptor (ER) antagonist ICI 182,780 into the uterine circulation reduced the increase in uterine blood flow in late ovine pregnancy by $37 \%$ [143], 2) prolonged infusion of $E_{2} \beta$ increased uterine blood flow and reduced uterine vascular resistance in non-pregnant, ovariectomized sheep [144], 3) ex vivo treatment of uterine arteries of non-pregnant sheep with $E_{2} \beta$ and progesterone lowered uterine arterial myogenic tone [145], and 4) acute estrogen treatment could also cause vasodilation and increased uterine blood flow [146,147]. Several mechanisms have been shown to contribute to estrogen's actions in uterine vasculature: 1) acutely stimulating both eNOS activity/NO production in endothelial cells $[148,149]$ and large conductance $\mathrm{Ca}^{2+}$ activated $\mathrm{K}^{+}\left(\mathrm{BK}_{\mathrm{Ca}}\right)$ channel activity in vascular smooth muscle cells [148], and 2) genetically and epigenetically upregulating the expression of endothelial nitric oxide synthase (eNOS), cystathionine $\gamma$-lyase (CSE) and $\mathrm{BK}_{\mathrm{Ca}}$ channel $\beta 1$ subunit in uterine arteries and subsequently leading to increased $\mathrm{NO}$ and $\mathrm{H}_{2} \mathrm{~S}$ production as well as enhanced $\mathrm{BK}_{\mathrm{Ca}}$ channel activity [150-155].

The relative contribution of endogenous $\mathrm{E}_{2} \beta, \mathrm{NO}$ and $\mathrm{BK}_{\mathrm{Ca}}$ channels on basal uterine blood flow during pregnancy were explored in sheep using pharmacological tools (e.g., ER antagonist ICI 182,780, NOS inhibitor L-nitro-arginine methyl ester (L-NAME), and $\mathrm{BK}_{\mathrm{Ca}}$ channel blocker 
tetraethylammonium) $[143,156]$. It was found that NO negligibly contributed to the regulation of basal uterine blood flow in pregnancy. In contrast, both ICI 182,780 and tetraethylammonium reduced basal uterine blood flow by $40-50 \%$. Similarly, uterine arterial myogenic tone in pregnancy was primarily regulated by $\mathrm{BK}_{\mathrm{Ca}}$ channels but not by the endothelium $[153,157,158]$. Thus, pregnancy-induced upregulation of the $\mathrm{BK}_{\mathrm{Ca}}$ channel is a major determinant conferring the reduction in uterine vascular resistance and increase in uterine blood flow. On the other hand, eNOS probably contributed to attenuated vasocontraction [159-161] and enhanced vasodilation in pregnancy [162-167] as well as remodeling of uterine arteries (see below). Although pregnancy was found to increase $\mathrm{H}_{2} \mathrm{~S}$ biosynthesis in uterine arteries [168], the functional importance of $\mathrm{H}_{2} \mathrm{~S}$ in regulating uterine vascular resistance and uterine blood flow remains to be investigated.

Myogenic tone is a major contributor to vascular resistance and plays a critical role in regulating tissue/organ blood flow. Under physiological conditions, the ryanodine receptor (RyR)-BK $\mathrm{Ca}_{\mathrm{Ca}}$ chanel axis is the major mechanism to counter myogenic tone [169]. In vascular smooth muscle cells, $\mathrm{BK}_{\mathrm{Ca}}$ channels are activated by $\mathrm{Ca}^{2+}$ sparks mediated by RyRs to generate spontaneous transient outward $\left(\mathrm{K}^{+}\right)$currents (STOCs) and the $\mathrm{BK}_{\mathrm{Ca}}$ channel $\beta 1$ subunit functions as a primary $\mathrm{Ca}^{2+}$ sensor. The $\mathrm{Ca}^{2+}$ spark-STOC coupling promotes membrane hyperpolarization and closure of voltage-gated $\mathrm{Ca}^{2+}$ $\left(\mathrm{Ca}_{\mathrm{V}} 1.2\right)$ channels, leading to vasodilation. Uterine arterial myogenic tone decreased in pregnant mice and sheep [170-172]. In pregnant sheep, $\mathrm{BK}_{\mathrm{Ca}}$ channel $\beta 1$ subunit and ryanodine receptors (RyRs) were upregulated $[153,173]$. Consequently, $\mathrm{Ca}^{2+}$ sparks and STOCs as well as the coupling between these two events were enhanced in uterine arteries in pregnancy [173], thus promoting the attenuation of uterine arterial myogenic tone. These findings are consistent with reduced uterine vascular tone in pregnant sheep $[143,174]$ and reinforced by the observations that the $\mathrm{BK}_{\mathrm{Ca}}$ channel blocker tetraethylammonium locally infused into the uterine circulation significantly increased uterine vascular resistance and decreased basal uterine blood flow by $\sim 50 \%$ in pregnant sheep and had no effect in non-pregnant animals $[148,175,176]$. Intriguingly, myogenic tone was found higher in uterine arteries of human and rat in pregnancy $[177,178]$ and its implication in pregnancy-induced increase in uterine blood flow is unclear currently. Uterine arteries also displayed both blunted responses to vasoconstrictors angiotensin II and norepinephrine $[159,161]$ and enhanced endothelium-dependent vasorelaxation [162,164-167]. Ultimately, the structural and functional modifications convert uterine arteries from low-flow, high-resistance to high-flow, low-resistance vessels, allowing to sufficiently perfuse the placenta and to accommodate the demands of the growing fetus. However, failure to structurally and functionally transform uterine arteries would increase uterine vascular resistance and decrease uteroplacental blood flow, leading to pregnancy complications such as preeclampsia and IUGR.

\subsection{Spiral Artery Maltransformation and Uterine Vascular Maladaptation in Compromised Pregnancies}

In normal pregnancy, the remodeling of spiral arteries not only occurs in decidua but also in one-third of myometrium. Brosens et al. first observed that preeclampsia lacks trophoblast invasion of myometrial spiral arteries about half a century ago [179]. This phenomenon is often termed 'shallow trophoblast invasion'. Impaired trophoblast invasion of spiral arteries in decidua and myometrium were subsequently confirmed in more cases of preeclampsia and IUGR [180-184]. Both preeclampsia and IUGR displayed less media disruption in myometrial vessels [184]. Not surprisingly, the caliber of spiral arteries in decidua in preeclamptic pregnancy was comparable to that in the non-pregnant state $(\sim 200 \mu \mathrm{m})$ [179]. Similarly, radial arteries in preeclamptic women had a small diameter than those in normal pregnant women [185]. In the IUGR model of eNOS-deficient mice, eNOS deletion impaired pregnancy-induced increase in diameter of uterine arteries $[186,187]$.

The functional adaptation of uterine arteries is also disturbed in preeclampsia and IUGR. Uterine arterial vascular resistance increased, whereas uterine blood flow reduced in both complications [188-193]. Increased uterine vascular resistance and reduced uteroplacental blood flow were simulated in a rat model of preeclampsia induced by testosterone injection [194]. Although uterine 
arterial myogenic tone was not altered in myometrial arteries in preeclamptic patients [195], it was increased in high altitude pregnant sheep and in a rat model of preeclampsia induced by reduced uterine blood flow [196,197]. In addition, flow-mediated relaxation of myometrial arteries was lost in preeclampsia [195]. Moreover, the endothelium-dependent relaxation of myometrial arteries was impaired in preeclampsia [198-201].

Gestational hypoxia at high altitude is associated with 3-fold increase in the incidence of IUGR and preeclampsia [202,203]. Human pregnancy at high altitude markedly reduced remodeling of decidual spiral arteries [204] and diminished NO-dependent vasorelaxation of myometrial arteries [205]. In Colorado, pregnant women at 3,100 $\mathrm{m}$ had $26 \%$ smaller uterine artery diameter than their counterparts at 1,600 $\mathrm{m}$ [206]. Consequently, pregnancy-induced increase in uterine blood flow was attenuated at high altitude [206,207]. In a sheep model of high-altitude pregnancy, uterine vascular resistance increased owing to increased uterine arterial myogenic tone [172,196]. Aberrant uterine vascular adaptation was also demonstrated in other animal models of IUGR and preeclampsia. In rodent models of preeclampsia induced by surgically induced-reduced uterine perfusion pressure (RUPP) and by testosterone-infusion, uterine arteries displayed increased myogenic tone, enhanced vasoconstriction to phenylephrine and angiotensin II, and reduced endothelium-dependent relaxation $[197,208]$.

\subsection{Impaired Trophoblast Invasion by miRNAs in Preeclampsia and IUGR}

As aforementioned, trophoblast migration/invasion is essential for the transformation of spiral arteries. The migration/invasion of EVTs in the maternal-fetal interface is tightly controlled by various autocrine and paracrine factors such as cytokines, growth factors, and chemokines. These factors activate a variety of signaling pathways including mitogen-activated protein kinases (MAPKs), phosphoinositide 3-kinase (PI3K)/protein kinase B (AKT), JAK-STAT, Wnt, transforming growth factor $\beta$ (TGF- $\beta$ ), insulin-like growth factor (IGF), NOTCH and other signal pathways $[209,210]$. Notably, cross-talks may occur between/among different pathways. Activation of these pathways often leads to altered expression of genes controlling trophoblast migration/invasion. Although etiologies of preeclampsia and IUGR are not fully understood, these two pregnancy complications are frequently associated with shallow trophoblast invasion and incomplete spiral artery remodeling [128,182]. MiRNAs are abundantly expressed in the placenta. Comparison among different stages of pregnancy and between normal and compromised pregnancies revealed that some of them are differentially expressed [31,32,50-52], suggesting that miRNAs could regulate trophoblast function and invasion via targeting specific genes in both physiological and pathological conditions (Figure 2).

\subsubsection{MAPK Signaling Pathway}

The MAPK signaling pathway plays an important role in transmitting extracellular signals into cellular responses. Activation of this pathway promotes the transcription of genes that encode proteins involved in the regulation of many cellular processes including differentiation, proliferation, motility and apoptosis [211]. Evidence of the involvement of the MAPK signaling pathway in trophoblast invasion primarily came from the use of pharmacological tools and trophoblast cell lines. 


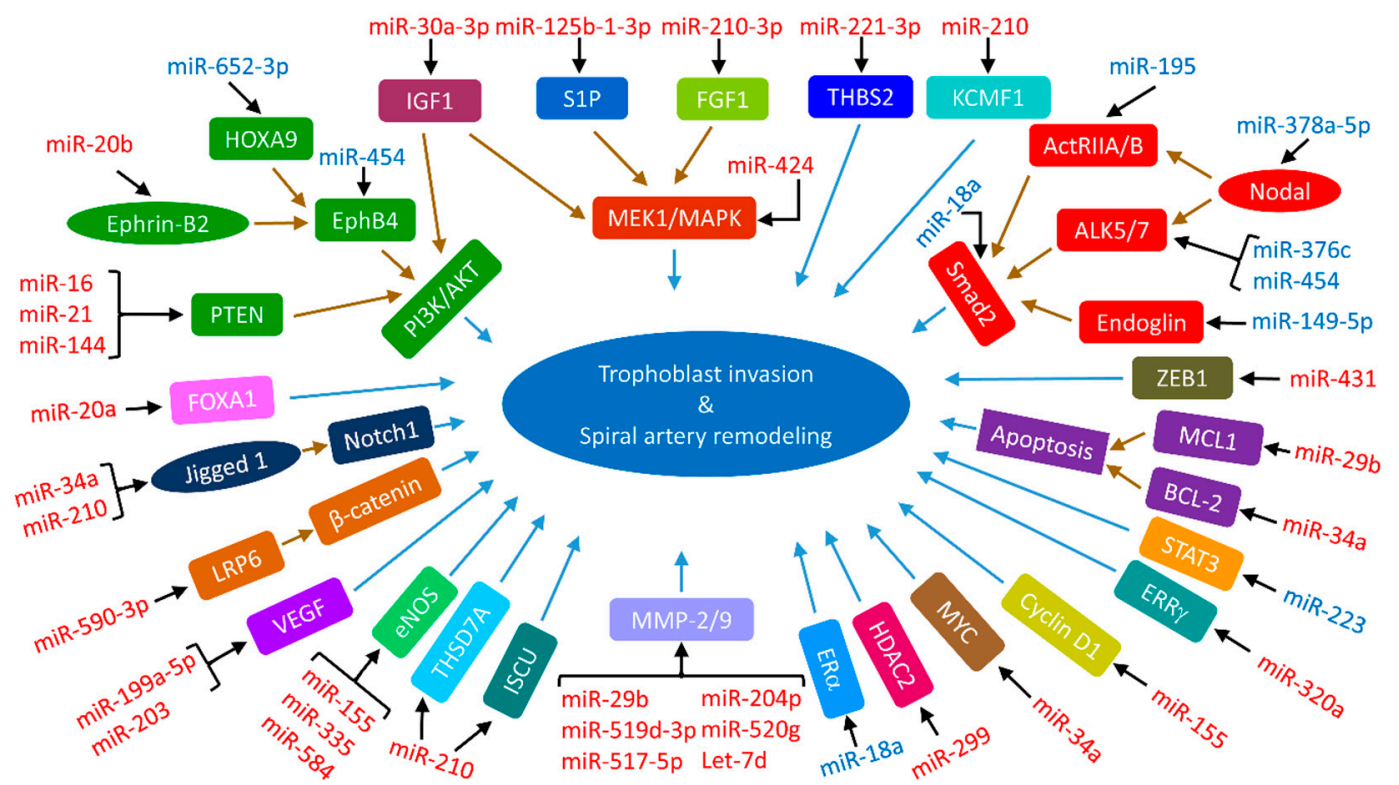

Figure 2. Dysregulated miRNAs and their targets involved in trophoblast invasion in preeclampsia and IUGR. The dysregulation of miRNAs (upregulated miRNA is denoted in red and downregulated miRNA is marked in blue) alters the expression of target gene(s) (linked with a black arrow) of different signaling pathways. Notably, the upregulated miRNA reduces target gene expression, whereas the downregulated miRNA increases target gene expression. In some cases, the miRNA-induced alteration of target gene expression leads to a cascade of signaling events (connected with a brown arrow(s)). Consequently, the altered signaling element(s)/pathway(s) instigates impairment of trophoblast invasion and subsequent failure in modeling of spiral arteries (linked with a blue arrow).

The ERK1/2 MAPK inhibitor U0126 decreased both MAPK phosphorylation and epidermal growth factor (EGF)-triggered HTR8/SVneo cell migration [212,213] or leukemia inhibitory factor (LIF)-induced JEG-3 cell invasion [214]. Blockade of ERK1/2 MAPK and p38 MAPK with U0126 and SB203580, respectively, also suppressed BeWo cell invasion [215] and EGF-stimulated SGHPL-4 cell motility [216]. However, hepatocyte growth factor (HGF)-stimulated SGHPL-4 cell motility was only reduced by ERK1/2 MAPK inhibition but not p38 MAPK inhibition [217]. Preeclampsia was found to be associated with decreased MAPK activation in both placenta and invasive trophoblasts as evidenced by a decrease in the abundance of phospho-MAPK $[218,219]$. In addition, the catalytic activity of p38 MAPK and level of phospho-p38 MAPK were also reduced in preeclamptic placentas [220]. Huang et al. demonstrated that miR-424 was upregulated in IUGR placentas [116]. MEK1 is the enzyme that catalyzes the phosphorylation of MAPK/ERK. MEK1 encoding gene MAP2K1 was found to be a target of miR-424 and its expression was negatively correlated with miR-424 levels in IUGR placenta. Both miR-141-5p and phospho-MAPK1 were downregulated in preeclamptic placentas [219]. Activating transcription factor 2 (ATF2) was the target of miR-141-5p and inhibiting miR-141-5p increased ATF2 expression, which would in turn promote the level of dual-specificity phosphatase 1 (DUSP1), an enzyme deactivating MAPK by dephosphorylating the threonine and the tyrosine residues within MAPKs activation site. Thus, downregulated miR-141-5p could indirectly impair phospho-MAPK1 abundance in preeclamptic placentas. Fibroblast growth factors (FGFs) were shown to promote ovine trophoblast invasion via activating MAPK [221]. The expression of FGF1 in IUGR were repressed by miR-210-3p, which could inhibit trophoblast invasion [115]. Sphingosine-1-phosphate (S1P) is a bioactive sphingolipid metabolite that participates in regulating cell migration, differentiation and survival via interacting its G protein-coupled S1P receptors (S1PRs) [222]. The binding of S1P to the S1PR led to activation MAPK signal pathway and increased production of MMP-2, ultimately promoting invasion of HTR8/SVneo cells [223]. MiR-125b-1-3p level in preeclamptic placentas was elevated [76]. This miRNA was found to target S1PR1, resulting in impaired trophoblast invasion. 
Anton et al. showed that miR-210 inhibited the invasion of primary extravillous trophoblast isolated from first-trimester villous tissue [224]. Intriguingly, the ERK1/2 MAPK inhibitor U0126 ablated miR-210-induced inhibitory effect. This contrasts with the pro-invasive effect of MAPK signaling pathway discussed above. It is not clear whether the use of different cell lines was accountable for the discrepancy.

\subsubsection{PI3K/AKT Signaling Pathway}

The PI3K/AKT signaling pathway is activated by a variety of extracellular stimuli including EGF and IGF-1. Activated PI3K phosphorylates and activates AKT, which in turn phosphorylates a wide range of substrates involved in cell proliferation, metabolism, survival, and motility [225]. This signaling cascade can be terminated by phosphatase and tensin homolog (PTEN) that dephosphorylates PIP3 and converts it back to $\mathrm{PIP}_{2}$ [226]. Like MAPK signaling pathway, the PI3K/AKT signaling pathway is also important for trophoblast invasion [227]. This pathway in trophoblasts appeared to be impaired in preeclampsia [228]. Both preeclamptic and IUGR placentas exhibited reduced expression of miR-16, miR-21, and miR-144 [61,72,113]. PTEN appeared to be the direct of miR-16, miR-21, and miR-144 and the downregulation of these miRNAs could enhance PTEN-mediated inhibition on PI3K/AKT signaling pathway and consequently inhibited trophoblast migration and invasion.

\subsubsection{TGF- $\beta$ Signaling Pathway}

The TGF- $\beta$ signaling is involved in regulating many cellular processes including cell proliferation, differentiation, apoptosis, and migration. The TGF- $\beta$ superfamily of ligands includes TGF $\beta$ s, activins, Nodal, and bone morphogenetic proteins (BMPs). The TGF- $\beta$ cascade is initiated by the binding of TGF- $\beta$ ligands to the type II (ActRIIA, ActRIIB, BMPRII, T $\beta$ RII and AMHRII) and type I (ALK1-7) receptors that are serine/threonine kinases and phosphorylate and activate receptor-regulated Smads (R-Smads, including Smad1, Smad2, Smad3, Smad5 and Smad8/9). The phosphorylated Smads associate with SMAD4 to form a heterodimeric complex which enters into the nucleus to regulate gene expression [229,230]. In general, activation of this pathway exerts an inhibitory effect on trophoblast migration and invasion [231-234]. Several components of the TGF- $\beta$ signaling pathway are targets of aberrantly expressed miRNAs in pregnancy complications. MiR-218-5p expression was suppressed in preeclamptic placentas and miR-218-5p inhibition was found to reduce trophoblast invasion via targeting TGFB2 [79]. Nodal, ALK5 and ALK7 were all upregulated in preeclamptic and IUGR placentas $[233,235]$. NODAL is a target of miR-378a-5p. Preeclampsia reduced placental miR-378a-5p expression and subsequently relieved NODAL repression, resulting in suppressed outgrowth and spreading of extravillous trophoblast cells in first trimester placental explants [33]. Both ActRIIA and ActRIIB were found to be upregulated and miR-195 downregulated in preeclamptic placentas [88,236]. It appeared that dysregulated miR-195-induced upregulation of ActRIIA encoding gene $A C V R 2 A$ and ActRIIB encoding gene $A C V R 2 B$ impaired the invasion of HTR8/SVneo cells. Similarly, both miR-454 and miR-376c, targeting ALK5 encoding gene TGFBR1 and/or ALK7 encoding gene ACVR1C, respectively, were downregulated in preeclamptic placentas and reduced HTR8/SVneo cell invasion and placental explant outgrowth [34,90]. Endoglin, an accessory receptor for TGF- $\beta$, negatively regulates trophoblast invasion $[237,238]$. The expression of endoglin was elevated in preeclamptic placentas and trophoblasts [75,239]. ENG is the target of miR-149-5p. The upregulation of endoglin due to downregulation of miR-149-5p in the preeclamptic placenta subsequently inhibited trophoblast invasion [75]. SMAD2-targeting miR-18a was downregulated in preeclamptic placenta, thus relieving $S M A D 2$ repression and impairing trophoblast invasion [43].

\subsubsection{Wnt Signaling Pathway}

The other important regulator of cell migration is the Wnt signaling pathway. This pathway involves binding of Wnt ligands to the Frizzled $(\mathrm{Fz})$ family of receptors and to low density lipoprotein receptor-related protein 5/6 (LRP5/6) co-receptors, using $\beta$-catenin as a transcriptional coactivator to 
regulate a variety of cellular activity including cell proliferation and migration [240]. Wnt signaling is also crucial for trophoblast invasion $[241,242]$. Wnt1, $\beta$-catenin, and LRP6 were downregulated in preeclamptic placentas [243-245]. MiR-590-3p repressed LRP6 expression by targeting LRP6 which subsequently reduced $\beta$-catenin, MMP-2 and MMP-9 expression, ultimately inhibiting trophoblast migration and invasion [246]. Consistently, downregulation of LRP6 with siRNA also reduced HTR6/SVneo cell invasion [245].

\subsubsection{Notch Signaling Pathway}

The Notch signaling pathway plays a pivotal role in regulating cell proliferation, differentiation, migration and apoptosis. The core components of Notch signaling pathway consist of Notch receptors (Notch1-4) and five ligands (Jagged 1/2 and Dll 1, 3, and 4). Ligand binding to Notch leads to cleavage and release of the Notch intracellular domain (NICD), which then travels to the nucleus to regulate transcriptional activity [247]. Notch signaling pathway also participates in placental development [248,249]. The expression of Notch signaling components such as Notch 2/3, Dll 3/4 and Jagged 1/2 were downregulated in preeclamptic placentas [250-254]. Downregulation of Notch 2 with a small hairpin RNA in BeWo cells inhibited both migration and invasion [255]. Both miR-34a and miR-210, which were overexpressed in preeclamptic and/or IUGR placentas $[36,95,256]$, contributed to NOTCH1 and JAG1 downregulation that led to impaired trophoblast migration and invasion $[97,254,257]$.

\subsubsection{EphrinB2-EphB4 Signaling Pathway}

The Eph receptor-interacting protein (ephrin)/erythropoietin-producing hepatocellular (Eph) receptor signaling involves various Eph receptor tyrosine kinases and membrane-tethered ligands [258]. The Eph receptor family consists of nine EphAs and five EphBs. Among them, the ephrin-B2-EphB4 cascade plays a critical role in angiogenesis [259] and is also involved in trophoblast invasion/spiral artery remodeling [260]. Placental EphB4 was increased in preeclampsia, resulting in inhibition of PI3K/AKT signaling pathway [261]. Moreover, enhanced expression of EphB4 was found to suppress trophoblast invasion [262]. MiR-454 was decreased, whereas EphB4 was increased in preeclamptic placenta [89]. EPHB4 was confirmed to be the target of miR-454 and miR-454 inhibition reduced trophoblast invasion. HOXA9 could directly bind to EPHB4 promoter and increased the expression of EPHB4, and both of them were increased in preeclamptic placentas [263]. Knockdown of HOXA9 increased migration and invasion of HTR-8/SVneo cells through targeting $E P H B 4$, confirming the inhibitory effect of EphB4 on trophoblast invasion. Placental miR-652-3p that targets HOXA9, was decreased in preeclampsia [108]. Inhibition of miR-652-3p enhanced EPHB4 expression and impaired invasion of HTR-8/SVneo cells. However, Zhang et al. showed that HOXA9 was downregulated in response to elevated miR-210 in preeclamptic placentas [264]. Wang et al. reported that preeclampsia increased miR-20b expression along with reduced level of Ephrin-B2 in the placenta, probably due to Ephrin-B2 encoding gene EFNB2 being targeted by miR-20b [30].

\subsubsection{Insulin-like Growth Factor 1 (IGF-1) Signaling Pathway}

The major components of IGF-1 signaling axis include IGF-1/2 and IGF1R. The binding of IGFs to IGFRs initiates the phosphorylation cascade leading to activation MAPK and PI3K/AKT pathways [265]. The IGF-1 signaling pathway is also implicated in placental development [266,267]. Reduced expression of IGF-1 was observed in preeclamptic and IUGR placentas [268,269]. Elevated miR-30a-3p was observed in preeclamptic placenta [68]. IGF1 was found to be the direct target of miR-30a-3p. Ectopic overexpression of miR-30a-3p suppressed both expression of IGF1 in HTR-8/SVneo cells and invasion of JEG-3 cells. Upregulated miR-141 in preeclamptic and IUGR placentas targeted a zinc finger protein encoding gene PLAG1 and subsequently impaired IGF2 expression, which in turn reduced trophoblast invasion [78,112]. 


\subsubsection{Matrix Metalloproteinases (MMPs)}

The invasion of spiral arteries by trophoblasts requires degrading extracellular matrix mediated by MMPs [270]. Among MMPs, MMP-2 and MMP-9 appear to play a crucial role in regulating trophoblast invasion [271]. The expression of MMP-2/9 displayed a temporal pattern: slight dominance of pro-MMP2 over pro-MMP-9 in 6-8 week trophoblasts and supremacy of pro-MMP-9 in trophoblasts from 9 to 11 weeks of gestation [272]. The expression of MMP-2/9 was downregulated in preeclamptic and IUGR placentas [273]. MMP-9 deficiency in pregnant mice simulated clinical features of preeclampsia and IUGR [274]. MMP2 and MMP9 are targeted by many miRNAs, which may contribute to the pathogenesis of preeclampsia and IUGR. MiR-20b, miR-29b, miR-517-5p, miR-519d-3p and miR-520g were upregulated in preeclamptic placentas and all of them targeted MMP2 to suppress trophoblast invasion $[67,106,110,111,275]$. The invasion of trophoblasts mediated by MMP-9 was impaired by miR-204 [276]. MiR-346 and miR-582-3p regulate endocrine gland-derived vascular endothelial growth factor (EG-VEGF)-induced trophoblast invasion through repressing MMP2 and MMP9 [277]. Chemokine CXCL6 inhibited trophoblast cell migration and invasion by suppressing MMP-2 activity in human first-trimester placenta [278]. CXCL6 was a direct target of miR-519d [279]. The expression of miR-519d was reduced in preeclamptic and IUGR placentas [51], which would then enhance CXCL6's inhibitory effect on trophoblast invasion. Placental miR-141 was increased in both preeclampsia and IUGR [78,112]. It could suppress trophoblast invasion through targeting the chemokine CXCL12 $\beta$ encoding gene CXCL12B, resulting in subsequent MMP2 downregulation under hypoxia [280]. The increased expression of let-7d in preeclamptic placentas decreased both MMP2 and MMP9 expression and suppressed trophoblast migration, although it was not determined whether MMP2 and MMP9 were targets of let-7d [58]. Since $M M P-2 / 9$ expression is also regulated by various signaling pathways such as MAPK, PI3K/AKT, Nodal, Wnt and TGF- $\beta$ signal pathways, miRNAs which disrupted these pathways could also indirectly impaired $M M P-2 / 9$ expression, leading to impaired trophoblast invasion [76,80,223,228,246,281,282].

\subsubsection{VEGF}

VEGF plays an important role in placenta angiogenesis [283]. In addition to its pro-angiogenesis, VEGF also promotes trophoblast invasion. Using the human EVT cell line SGHPL-4 cells, Lash et al. revealed that VEGF functioned as a chemoattractant to increase trophoblast invasion and motility [284,285]. Several studies showed that miRNAs could target VEGF to impair trophoblast invasion. It was reported that expression of miR-199a-5p and miR-203 was increased in preeclamptic placentas [94]. VEGFA was the target of miR-199a-5p and miR-203. Both miRNAs inhibited migration and invasion of HTR-8/SVneo cells by downregulating VEGFA. Similarly, in a rodent model of preeclampsia, upregulated expression of miR-155 was associated with VEGF repression in the placenta [286]. These observations are consistent with the findings of VEGF downregulation in trophoblasts of preeclamptic and IUGR placentas $[287,288]$.

\subsubsection{0. eNOS}

The involvement of eNOS in regulating trophoblast invasion of uteroplacental artery was initially observed in guinea pig [289]. It was found that the invasion of trophoblasts only occurred when the vessels were dilated by the approaching trophoblasts expression eNOS. Subsequently, eNOS expression was observed in human EVTs [290]. Moreover, it was demonstrated that the endogenously produced NO was responsible for the invasion and motility of trophoblasts using the SGHPL-4 cell line expressing constitutive (eNOS) and inducible isoforms (iNOS) [291]. MiR-155, miR-335, and miR-584 were upregulated in preeclamptic placentas [44,84]. All of them targeted NOS3 to inhibit both eNOS expression and migration/invasion of HTR-8/SVneo cells. The functional importance of eNOS was further confirmed by the observation that NOS3 knockdown diminished annexin A4 overexpression-induced promotion of cell invasion in both HTR-8/SVneo and JEG-3 cells [228]. 
Moreover, pregnancy induced less increase in radius of uterine arteries in an eNOS-deficient $\left(\mathrm{eNOS}^{-/-}\right)$ mouse model of IUGR [186,292]. Thus, the dysregulation of NOS3 by miRNAs like miR-155, miR-335 and miR-584 could also potentially disrupt structural remodeling of large uterine arteries.

\subsubsection{Other Signaling Elements}

A variety of aberrantly expressed miRNAs in preeclamptic placentas have also found to act on other signaling elements to interrupt trophoblast invasion. STAT3 plays a critical role in trophoblast invasion [293]. The expression of miR-223 and STAT3 exhibited a reciprocal pattern in preeclamptic placentas: downregulation of miR-223 and upregulation of STAT3 [294]. STAT3 was targeted by miR-223 and miR-223 inhibition impaired trophoblast invasion. MiR-18a is downregulated in preeclamptic placentas [295]. An in vitro study revealed that miR-18a targeted ER $\alpha$ receptor encoding gene ESR1 and miR-18a repression reduced JEG-3 cell invasion [295]. This finding is consistent with the inhibitory effect of estrogen on EVT invasion of spiral arteries during early baboon pregnancy [296]. MYC is a regulator of many genes by binding to enhancer box sequences (E-boxes) [297]. Preeclamptic placentas displayed upregulated miR-34a and miR-34a inhibited trophoblast migration and invasion via targeting MYC [69]. The expression of miR-218 was enhanced in preeclamptic placentas and its ectopic expression reduced HTR-8/SVneo cell invasion via targeting LASP1, the gene encoding LIM and SH3 domain protein 1 (LASP1) [101]. LASP1 promoted tumor invasion and metastasis by releasing MMPs into the extracellular matrix [298]. It remains to be determined whether this mechanism is involved in miR-218-mediated inhibitory effect on trophoblast invasion. MiR-134 was upregulated in preeclamptic placentas and targeted integrin $\beta 1$ encoding gene ITGB1, resulting in inhibition of trophoblast invasion [299]. Upregulated miR-210 and miR-320a in preeclamptic and IUGR placentas interfered energy metabolism via targeting iron-sulfur cluster assembly enzyme encoding gene ISCU and estrogen-related receptor- $\gamma$ encoding gene $E R R G$, impairing trophoblast invasion $[95,300]$. Targeting cell cycle regulators by miRNAs could also impair trophoblast invasion. MiR-155 reduced trophoblast invasion via targeting cyclin D1 encoding gene CCND1 [301]. The upregulated miR-210 reduced the expression of potassium channel modulatory factor 1 (KCMF1) and thrombospondin type I domain containing 7A (THSD7A) in preeclamptic placentas, resulting reduced trophoblast invasion $[96,98]$. Upregulated miR-20a in preeclamptic placenta was found to inhibit trophoblast migration and invasion via targeting FOXA1 [62]. MiR-431, upregulated in preeclamptic placentas, increased E-cadherin via targeting the transcription factor zinc finger E-box-binding homeobox 1 (ZEB1) leading to reduced migration and invasion of trophoblasts [105]. Upregulated placental miR-299 in preeclampsia suppressed migration and invasion of trophoblasts via targeting histone deacetylase 2 (HDAC2) [102]. Thrombospondin 2 (THBS2) was found to repress tumor growth and angiogenesis [302]. Its expression was elevated in preeclamptic placentas due to reduced miR-221-3p expression. Consequently, miR-221-3p inhibitor was found to reduce trophoblast migration and invasion in HTR-8/SVneo cells [81].

Apoptosis of EVTs was increased in early-onset preeclampsia and IUGR, which could in turn impair trophoblast invasion $[182,303]$. This mechanism appeared to be involved in some miRNAs' adverse effect on trophoblast migration and invasion in preeclampsia and IUGR. For example, increased expression of miR-29b in preeclamptic placentas could induce apoptosis and reduce of trophoblasts via downregulating myeloid cell leukemia 1 encoded by MCL1, an anti-apoptotic member of the B-cell lymphoma 2 (Bcl-2) family of apoptosis-regulating proteins [67]. Similarly, elevated miR-34a in preeclamptic placentas promoted trophoblast apoptosis via repressing anti-apoptotic B-cell lymphoma 2 encoded by $B C L 2$ [70].

\section{5. miRNAs in Maladaptation of Uterine Vascular Function in Preeclampsia and IUGR}

Besides impaired trophoblast invasion and spiral artery remodeling, the functional adaptation of uterine vasculature is also disrupted in preeclampsia and IUGR. Several important factors involved in the adaptive changes of uterine vascular function are dysregulated in preeclampsia and IUGR. 
Placental estrogen biosynthesis was impaired due to the downregulation of $17 \beta$-hydroxysteroid dehydrogenase $1(17 \beta-H S D 1)$ and aromatase [29,304-306] in these pregnancy complications. Downregulation of $\mathrm{BK}_{\mathrm{Ca}}$ channel $\beta 1$ subunit was observed in placental chorionic plate arteries in preeclampsia and uterine arteries in high-altitude pregnancy $[172,307]$. Concurrently, $\mathrm{BK}_{\mathrm{Ca}}$ channel-mediated attenuation of uterine arterial myogenic tone was diminished [308]. The expression of CSE was also reduced in preeclamptic and IUGR placentas [114,309]. Placental expression of eNOS remains controversy in preeclampsia and IUGR, downregulation, upregulation or no change were reported [310]. eNOS was downregulated in placental chorionic plate arteries in preeclampsia [311] but upregulated in uterine arteries in high altitude pregnancy [312]. Not surprisingly, circulating $E_{2} \beta$ and hydrogen sulfide $\left(\mathrm{H}_{2} \mathrm{~S}\right)$ as well as NO bioavailability was reduced in preeclamptic and IUGR pregnancies [304,305,309,313-316].

Accumulating evidence suggest that aberrantly expressed miRNAs contributed to the dysregulation of estrogen biosynthesis, $\mathrm{NO}$ signaling, $\mathrm{H}_{2} \mathrm{~S}$ signaling and $\mathrm{BK}_{\mathrm{Ca}}$ channel activity, leading to the maladaptation of uteroplacental circulation in preeclampsia and IUGR (Figure 3). These miRNAs could be either generated locally in the uteroplacental tissues or produced in the placenta and uptaken from the circulation [317]. Circulating microRNAs, either freely or within extracellular vesicles (EVs), could be transported to cells to regulate expression of target genes. For example, placental syncytiotrophoblast EVs (STBEVs) was shown to be internalized into primary human coronary artery endothelial cells and miRNAs inside STBEVs could be transferred into endoplasmic reticulum and mitochondria of the recipient cells, resulting downregulation of specific target genes [318].

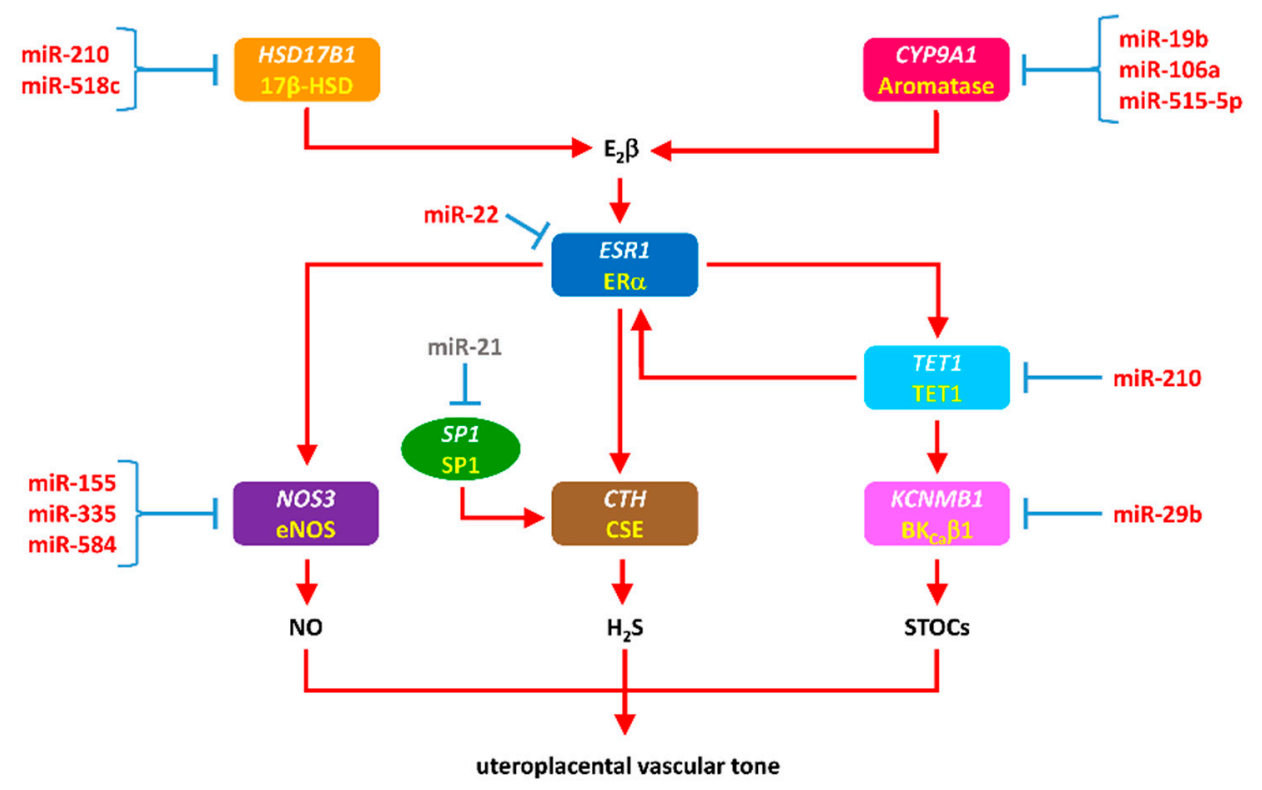

Figure 3. A flowchart showing potential gene targets of aberrantly expressed miRNA on uteroplacental vascular function in preeclampsia and IUGR. During pregnancy, estrogen is predominantly produced in the placenta. $17 \beta$-hydroxysteroid dehydrogenase-1 (17 $\beta$-HSD1) and aromatase are two key enzymes in estrogen biosynthesis. $17 \beta$-estradiol $\left(\mathrm{E}_{2} \beta\right)$ plays a central role in regulating uteroplacental vascular function during pregnancy by enhancing the expression of ten-eleven translocation methylcytosine dioxygenase 1 (TET1), endothelial nitric oxide synthase (eNOS), cystathionine $\gamma$-lyase (CSE) and $\mathrm{BK}_{\mathrm{Ca}}$ channel $\beta 1$ subunit $\left(\mathrm{BK}_{\mathrm{Ca}} \beta 1\right)$. Various aberrantly expressed miRNAs (upregulated miRNA in red) in compromised pregnancies have been show to target genes encoding 17 $\beta$-HSD1, aromatase, TET1, eNOS, CSE and $\mathrm{BK}_{\mathrm{Ca}} \beta 1$ (depicted in italics) and decrease the expression of these targets. (Note that both upregulation and downregulation of miR-21 (in grey) have been reported in compromised pregnancies.) The downregulation of these proteins subsequently reduces the generation of $E_{2} \beta$, nitric oxide $(\mathrm{NO})$, hydrogen sulfide $\left(\mathrm{H}_{2} \mathrm{~S}\right)$ and spontaneous transient outward currents (STOCs), leading to dysfunction of uteroplacental vasculature. 
Aromatase encoded by CYP19A1 and 17 $\beta-H S D 1$ encoded by HSD17B are two key enzymes in estrogen biosynthesis in the placenta. Aromatase catalyzes the conversion of androstenedione to estrone (E1) and testosterone to $E_{2} \beta$, whereas $17 \beta-H S D$ catalyzes the conversion of $E 1$ to the biologically potent $E_{2} \beta$. Both preeclampsia and IUGR are associated with abnormal steroidogenesis and metabolism. The expression of CYP19A1 and 17/-HSD1 in the placenta was downregulated in preeclamptic and IUGR pregnancies $[29,304,305,319,320]$, leading to reduced circulating $E_{2} \beta[304,305,315,316]$. The downregulation of aromatase and $17 \beta-H S D$ in the placenta was apparently conferred in part by dysregulation of given miRNAs. The expression of miR-19b, miR-106a, miR-210, miR-515-5p and miR-518c was significantly upregulated in preeclampsia and/or IUGR $[29,60,93,95]$. CYP19A1 was a confirmed target of miR-19b, miR-106a, and miR-515-5p, whereas HSD17B was targeted by miR-210 and miR-518c $[29,60,93]$. In addition, miR-22 was found to inhibit CYP19A1 expression indirectly by targeting ER $\alpha$ encoding gene ESR1 [319]. ERR $\gamma$ a constitutively active orphan nuclear receptor, stimulated HSD17B1 expression in the placenta [306]. The expression of ESRRG could be inhibited by elevated miR-320a in preeclamptic placenta [103]. Therefore, the dysregulated miR-320a may contribute to HSD17B1 repression in preeclamptic placenta.

The upregulation of ESR1 and $\mathrm{BK}_{\mathrm{Ca}}$ channel $\beta 1$ subunit encoding gene KCNMB1 in uterine arteries in pregnancy was mainly achieved through an epigenetic mechanism [321]. Both genes were repressed in uterine arteries of in nonpregnant state due to hypermethylation $[154,322]$. Elevated $E_{2} \beta$ in normal pregnancy activated ER $\alpha$ in uterine arteries, which subsequently upregulated Ten-eleven translocation methylcytosine dioxygenase 1 (TET1), an enzyme that participates in active DNA demethylation. TET1-initiated demethylation process in turn could promote ESR1 expression, forming a positively feedback loop [322]. In addition, TET1-induced demethylation also upregulated KCNMB1 expression in uterine arteries [321]. The expression of ESR1 in uterine arteries and placentas was reduced in preeclampsia and high-altitude pregnancy [196,322,323]. The expression of ESR1 could be regulated by miRNAs directly or indirectly. Placental miR-22 was upregulated in preeclampsia and miR-22 binding to the 3'-UTR of ESR1 could repress ESR1 expression [319]. Increased miR-210 in uteroplacental tissues was observed in preeclamptic, IUGA and high-altitude pregnancies and TET1 was a direct target of miR-210 [55,95,174,224]. The downregulation of TET1 consequently resulted in repression of both ESR1 and KCNMB1 [55,174,322]. The downregulation of ESR1 could in turn lead to the repression of NOS3 and CTH. In addition, NOS3 and KCNMB1 could also be directly targeted by given miRNAs. NOS3 was downregulated in the placenta by upregulated miR-155, miR-335 and miR-584 in preeclamptic pregnancy [44,84]. An abstract presented in Experimental Biology 2018 showed that upregulated miR-29b promoted downregulation of KCNMB1, leading to reduced $\mathrm{BK}_{\mathrm{Ca}}$ channel activity in pulmonary artery smooth muscle cells from patients with idiopathic pulmonary arterial hypertension [324]. TET1 was also found to be the direct target of miR-29b [325]. Moreover, the expression of CSE encoding gene CTH was indirectly inhibited through miR-21-induced downregulation of transcript factor specificity protein-1 (SP1) [326]. Given that uteroplacental miR-29b and miR-21 were upregulated in preeclampsia and IUGR $[67,113,114,327]$, it is probably that NOS3, $C T H$ and KCNMB1 in uteroplacental vessels are also targeted directly or indirectly by these miRNAs. Owing to their critical roles in regulating uterine vascular function, the downregulation of ESR1, NOS3, $C T H$ and KCNMB1 would be expected to impair uteroplacental vascular adaptation and to increase uteroplacental vascular resistance, contributing to the development of compromised pregnancies.

\section{Concluding Remarks}

A successful pregnancy is dependent on adequate perfusion of the placenta to supply the fetus with oxygen and nutrients, which relies on appropriate adaptation of uteroplacental circulation. Placental insufficiency caused by inadequate remodeling of spiral arteries and functional maladaptation of uterine vasculature is believed to contribute to the development of both preeclampsia and IUGR. Differentially expressed miRNAs are commonly observed in preeclamptic and IUGR placentas. Increasing evidence suggests that dysregulated miRNAs play important roles in impairing 
uteroplacental vascular function by targeting numerous genes of multiple signal transduction pathways. Trophoblast invasion starts at $\sim 8$ week of gestation and completes in the middle of second trimester. However, current information on the dysregulation of placental miRNAs in preeclampsia and IUGR were mostly obtained from term placentas. MiRNA expression varies with gestational age. Thus, knowledge on placental miRNA expression in the early stage of preeclamptic and IUGR pregnancy is a prerequisite to understand the impacts of dysregulated miRNAs on trophoblast invasion and remodeling of spiral arteries. Moreover, most studies only focused on a specific miRNA and one or a few target genes. As trophoblast invasion and uterine vascular adaptation are regulated by gene regulatory networks, further investigations are required to elucidate key molecular circuits and their coordination/integration that control these processes in normal and compromised pregnancies.

Author Contributions: Conceptualization and writing, X.-Q.H. and L.Z.

Funding: This work was funded by National Institutes of Health Grants HD083132 (L. Zhang), HL128209 (L. Zhang), and HL137649 (L. Zhang).

Conflicts of Interest: The authors declare no conflict of interest.

\section{References}

1. Alles, J.; Fehlmann, T.; Fischer, U.; Backes, C.; Galata, V.; Minet, M.; Hart, M.; Abu-Halima, M.; Grasser, F.A.; Lenhof, H.P.; et al. An estimate of the total number of true human miRNAs. Nucleic Acids Res. 2019, 47, 3353-3364. [CrossRef] [PubMed]

2. Sayed, D.; Abdellatif, M. MicroRNAs in development and disease. Physiol. Rev. 2011, 91, 827-887. [CrossRef] [PubMed]

3. American College of Obstetricians and Gynecologists. Hypertension in pregnancy. Report of the American College of Obstetricians and Gynecologists' Task Force on Hypertension in Pregnancy. Obstet. Gynecol. 2013, 122, 1122-1131. [CrossRef]

4. Tranquilli, A.L.; Dekker, G.; Magee, L.; Roberts, J.; Sibai, B.M.; Steyn, W.; Zeeman, G.G.; Brown, M.A. The classification, diagnosis and management of the hypertensive disorders of pregnancy: A revised statement from the ISSHP. Pregnancy Hypertens. 2014, 4, 97-104. [CrossRef]

5. Vayssiere, C.; Sentilhes, L.; Ego, A.; Bernard, C.; Cambourieu, D.; Flamant, C.; Gascoin, G.; Gaudineau, A.; Grange, G.; Houfflin-Debarge, V.; et al. Fetal growth restriction and intra-uterine growth restriction: Guidelines for clinical practice from the French College of Gynaecologists and Obstetricians. Eur. J. Obstet. Gynecol. Reprod. Biol. 2015, 193, 10-18. [CrossRef]

6. Phipps, E.A.; Thadhani, R.; Benzing, T.; Karumanchi, S.A. Pre-eclampsia: Pathogenesis, novel diagnostics and therapies. Nat. Rev. Nephrol. 2019, 15, 275-289. [CrossRef]

7. Goulopoulou, S. Maternal Vascular Physiology in Preeclampsia. Hypertension 2017, 70, 1066-1073. [CrossRef]

8. Lane-Cordova, A.D.; Khan, S.S.; Grobman, W.A.; Greenland, P.; Shah, S.J. Long-Term Cardiovascular Risks Associated with Adverse Pregnancy Outcomes: JACC Review Topic of the Week. J. Am. Coll. Cardiol. 2019, 73, 2106-2116. [CrossRef]

9. Huppertz, B. Placental origins of preeclampsia: Challenging the current hypothesis. Hypertension 2008, 51, 970-975. [CrossRef]

10. Kalafat, E.; Thilaganathan, B. Cardiovascular origins of preeclampsia. Curr. Opin. Obstet. Gynecol. 2017, 29, 383-389. [CrossRef]

11. Menendez-Castro, C.; Rascher, W.; Hartner, A. Intrauterine growth restriction-Impact on cardiovascular diseases later in life. Mol. Cell. Pediatr. 2018, 5, 4. [CrossRef] [PubMed]

12. Rashid, C.S.; Bansal, A.; Simmons, R.A. Oxidative Stress, Intrauterine Growth Restriction, and Developmental Programming of Type 2 Diabetes. Physiology 2018, 33, 348-359. [CrossRef] [PubMed]

13. Roberts, J.M.; Escudero, C. The placenta in preeclampsia. Pregnancy Hypertens. 2012, 2, 72-83. [CrossRef] [PubMed]

14. Burton, G.J.; Jauniaux, E. Pathophysiology of placental-derived fetal growth restriction. Am. J. Obstet. Gynecol. 2018, 218, S745-S761. [CrossRef]

15. Mouillet, J.F.; Ouyang, Y.; Coyne, C.B.; Sadovsky, Y. MicroRNAs in placental health and disease. Am. J. Obstet. Gynecol. 2015, 213, S163-S172. [CrossRef] 
16. Hayder, H.; O’Brien, J.; Nadeem, U.; Peng, C. MicroRNAs: Crucial regulators of placental development. Reproduction 2018, 155, R259-R271. [CrossRef]

17. Malnou, E.C.; Umlauf, D.; Mouysset, M.; Cavaille, J. Imprinted MicroRNA Gene Clusters in the Evolution, Development, and Functions of Mammalian Placenta. Front. Genet. 2018, 9, 706. [CrossRef]

18. Chiofalo, B.; Lagana, A.S.; Vaiarelli, A.; La Rosa, V.L.; Rossetti, D.; Palmara, V.; Valenti, G.; Rapisarda, A.M.C.; Granese, R.; Sapia, F.; et al. Do miRNAs Play a Role in Fetal Growth Restriction? A Fresh Look to a Busy Corner. Biomed. Res. Int. 2017, 2017, 6073167. [CrossRef]

19. Bounds, K.R.; Chiasson, V.L.; Pan, L.J.; Gupta, S.; Chatterjee, P. MicroRNAs: New Players in the Pathobiology of Preeclampsia. Front. Cardiovasc. Med. 2017, 4, 60. [CrossRef]

20. Yi, R.; Qin, Y.; Macara, I.G.; Cullen, B.R. Exportin-5 mediates the nuclear export of pre-microRNAs and short hairpin RNAs. Genes Dev. 2003, 17, 3011-3016. [CrossRef]

21. Desvignes, T.; Batzel, P.; Berezikov, E.; Eilbeck, K.; Eppig, J.T.; McAndrews, M.S.; Singer, A.; Postlethwait, J.H. miRNA Nomenclature: A View Incorporating Genetic Origins, Biosynthetic Pathways, and Sequence Variants. Trends Genet. 2015, 31, 613-626. [CrossRef] [PubMed]

22. Huntzinger, E.; Izaurralde, E. Gene silencing by microRNAs: Contributions of translational repression and mRNA decay. Nat. Rev. Genet. 2011, 12, 99-110. [CrossRef] [PubMed]

23. Treiber, T.; Treiber, N.; Meister, G. Regulation of microRNA biogenesis and its crosstalk with other cellular pathways. Nat. Rev. Mol. Cell. Biol. 2019, 20, 5-20. [CrossRef] [PubMed]

24. Vasudevan, S.; Tong, Y.; Steitz, J.A. Switching from repression to activation: microRNAs can up-regulate translation. Science 2007, 318, 1931-1934. [CrossRef]

25. Fabian, M.R.; Sonenberg, N.; Filipowicz, W. Regulation of mRNA translation and stability by microRNAs. Annu. Rev. Biochem. 2010, 79, 351-379. [CrossRef]

26. Donker, R.B.; Mouillet, J.F.; Chu, T.; Hubel, C.A.; Stolz, D.B.; Morelli, A.E.; Sadovsky, Y. The expression profile of C19MC microRNAs in primary human trophoblast cells and exosomes. Mol. Hum. Reprod. 2012, 18, 417-424. [CrossRef]

27. Morales-Prieto, D.M.; Chaiwangyen, W.; Ospina-Prieto, S.; Schneider, U.; Herrmann, J.; Gruhn, B.; Markert, U.R. MicroRNA expression profiles of trophoblastic cells. Placenta 2012, 33, 725-734. [CrossRef]

28. Morales-Prieto, D.M.; Ospina-Prieto, S.; Schmidt, A.; Chaiwangyen, W.; Markert, U.R. Elsevier Trophoblast Research Award Lecture: Origin, evolution and future of placenta miRNAs. Placenta 2014, 35, S39-S45. [CrossRef]

29. Ishibashi, O.; Ohkuchi, A.; Ali, M.M.; Kurashina, R.; Luo, S.S.; Ishikawa, T.; Takizawa, T.; Hirashima, C.; Takahashi, K.; Migita, M.; et al. Hydroxysteroid (17-beta) dehydrogenase 1 is dysregulated by miR-210 and miR-518c that are aberrantly expressed in preeclamptic placentas: A novel marker for predicting preeclampsia. Hypertension 2012, 59, 265-273. [CrossRef]

30. Wang, W.; Feng, L.; Zhang, H.; Hachy, S.; Satohisa, S.; Laurent, L.C.; Parast, M.; Zheng, J.; Chen, D.B. Preeclampsia up-regulates angiogenesis-associated microRNA (i.e., miR-17, -20a, and -20b) that target ephrin-B2 and EPHB4 in human placenta. J. Clin. Endocrinol. Metab. 2012, 97, E1051-E1059. [CrossRef]

31. Gu, Y.; Sun, J.; Groome, L.J.; Wang, Y. Differential miRNA expression profiles between the first and third trimester human placentas. Am. J. Physiol. Endocrinol. Metab. 2013, 304, E836-E843. [CrossRef] [PubMed]

32. Farrokhnia, F.; Aplin, J.D.; Westwood, M.; Forbes, K. MicroRNA regulation of mitogenic signaling networks in the human placenta. J. Biol. Chem. 2014, 289, 30404-30416. [CrossRef] [PubMed]

33. Luo, L.; Ye, G.; Nadeem, L.; Fu, G.; Yang, B.B.; Honarparvar, E.; Dunk, C.; Lye, S.; Peng, C. MicroRNA-378a-5p promotes trophoblast cell survival, migration and invasion by targeting Nodal. J. Cell Sci. 2012, 125, 3124-3132. [CrossRef] [PubMed]

34. Fu, G.; Ye, G.; Nadeem, L.; Ji, L.; Manchanda, T.; Wang, Y.; Zhao, Y.; Qiao, J.; Wang, Y.L.; Lye, S.; et al. MicroRNA-376c impairs transforming growth factor-beta and nodal signaling to promote trophoblast cell proliferation and invasion. Hypertension 2013, 61, 864-872. [CrossRef] [PubMed]

35. Yang, H.L.; Zhang, H.Z.; Meng, F.R.; Han, S.Y.; Zhang, M. Differential expression of microRNA-411 and 376c is associated with hypertension in pregnancy. Braz. J. Med. Biol. Res. 2019, 52, e7546. [CrossRef]

36. Pineles, B.L.; Romero, R.; Montenegro, D.; Tarca, A.L.; Han, Y.M.; Kim, Y.M.; Draghici, S.; Espinoza, J.; Kusanovic, J.P.; Mittal, P.; et al. Distinct subsets of microRNAs are expressed differentially in the human placentas of patients with preeclampsia. Am. J. Obstet. Gynecol. 2007, 196, e261-e266. [CrossRef] 
37. Hu, Y.; Li, P.; Hao, S.; Liu, L.; Zhao, J.; Hou, Y. Differential expression of microRNAs in the placentae of Chinese patients with severe pre-eclampsia. Clin. Chem. Lab. Med. 2009, 47, 923-929. [CrossRef]

38. Zhu, X.M.; Han, T.; Sargent, I.L.; Yin, G.W.; Yao, Y.Q. Differential expression profile of microRNAs in human placentas from preeclamptic pregnancies vs. normal pregnancies. Am. J. Obstet. Gynecol. 2009, 200, e661-e667. [CrossRef]

39. Enquobahrie, D.A.; Abetew, D.F.; Sorensen, T.K.; Willoughby, D.; Chidambaram, K.; Williams, M.A. Placental microRNA expression in pregnancies complicated by preeclampsia. Am. J. Obstet. Gynecol. 2011, 204, e112-e121. [CrossRef]

40. Mayor-Lynn, K.; Toloubeydokhti, T.; Cruz, A.C.; Chegini, N. Expression profile of microRNAs and mRNAs in human placentas from pregnancies complicated by preeclampsia and preterm labor. Reprod. Sci. 2011, 18, 46-56. [CrossRef]

41. Betoni, J.S.; Derr, K.; Pahl, M.C.; Rogers, L.; Muller, C.L.; Packard, R.E.; Carey, D.J.; Kuivaniemi, H.; Tromp, G. MicroRNA analysis in placentas from patients with preeclampsia: Comparison of new and published results. Hypertens. Pregnancy 2013, 32, 321-339. [CrossRef] [PubMed]

42. Choi, S.Y.; Yun, J.; Lee, O.J.; Han, H.S.; Yeo, M.K.; Lee, M.A.; Suh, K.S. MicroRNA expression profiles in placenta with severe preeclampsia using a PNA-based microarray. Placenta 2013, 34, 799-804. [CrossRef] [PubMed]

43. Xu, P.; Zhao, Y.; Liu, M.; Wang, Y.; Wang, H.; Li, Y.X.; Zhu, X.; Yao, Y.; Wang, H.; Qiao, J.; et al. Variations of microRNAs in human placentas and plasma from preeclamptic pregnancy. Hypertension 2014, 63, 1276-1284. [CrossRef] [PubMed]

44. Jiang, F.; Li, J.; Wu, G.; Miao, Z.; Lu, L.; Ren, G.; Wang, X. Upregulation of microRNA335 and microRNA584 contributes to the pathogenesis of severe preeclampsia through downregulation of endothelial nitric oxide synthase. Mol. Med. Rep. 2015, 12, 5383-5390. [CrossRef] [PubMed]

45. Zhang, C.; Li, Q.; Ren, N.; Li, C.; Wang, X.; Xie, M.; Gao, Z.; Pan, Z.; Zhao, C.; Ren, C.; et al. Placental miR-106a approximately 363 cluster is dysregulated in preeclamptic placenta. Placenta 2015, 36, 250-252. [CrossRef]

46. Lykoudi, A.; Kolialexi, A.; Lambrou, G.I.; Braoudaki, M.; Siristatidis, C.; Papaioanou, G.K.; Tzetis, M.; Mavrou, A.; Papantoniou, N. Dysregulated placental microRNAs in Early and Late onset Preeclampsia. Placenta 2018, 61, 24-32. [CrossRef]

47. Awamleh, Z.; Gloor, G.B.; Han, V.K.M. Placental microRNAs in pregnancies with early onset intrauterine growth restriction and preeclampsia: Potential impact on gene expression and pathophysiology. BMC Med. Genom. 2019, 12, 91. [CrossRef]

48. Higashijima, A.; Miura, K.; Mishima, H.; Kinoshita, A.; Jo, O.; Abe, S.; Hasegawa, Y.; Miura, S.; Yamasaki, K.; Yoshida, A.; et al. Characterization of placenta-specific microRNAs in fetal growth restriction pregnancy. Prenat. Diagn. 2013, 33, 214-222. [CrossRef]

49. Thamotharan, S.; Chu, A.; Kempf, K.; Janzen, C.; Grogan, T.; Elashoff, D.A.; Devaskar, S.U. Differential microRNA expression in human placentas of term intra-uterine growth restriction that regulates target genes mediating angiogenesis and amino acid transport. PLoS ONE 2017, 12, e0176493. [CrossRef]

50. Ostling, H.; Kruse, R.; Helenius, G.; Lodefalk, M. Placental expression of microRNAs in infants born small for gestational age. Placenta 2019, 81, 46-53. [CrossRef]

51. Hromadnikova, I.; Kotlabova, K.; Ondrackova, M.; Pirkova, P.; Kestlerova, A.; Novotna, V.; Hympanova, L.; Krofta, L. Expression profile of C19MC microRNAs in placental tissue in pregnancy-related complications. DNA Cell Biol. 2015, 34, 437-457. [CrossRef] [PubMed]

52. Hromadnikova, I.; Kotlabova, K.; Hympanova, L.; Krofta, L. Cardiovascular and Cerebrovascular Disease Associated microRNAs Are Dysregulated in Placental Tissues Affected with Gestational Hypertension, Preeclampsia and Intrauterine Growth Restriction. PLoS ONE 2015, 10, e0138383. [CrossRef] [PubMed]

53. Pritchard, C.C.; Cheng, H.H.; Tewari, M. MicroRNA profiling: Approaches and considerations. Nat. Rev. Genet. 2012, 13, 358-369. [CrossRef] [PubMed]

54. Hunt, E.A.; Broyles, D.; Head, T.; Deo, S.K. MicroRNA Detection: Current Technology and Research Strategies. Annu. Rev. Anal. Chem. 2015, 8, 217-237. [CrossRef] [PubMed]

55. Hu, X.Q.; Dasgupta, C.; Xiao, J.; Yang, S.; Zhang, L. Long-term high altitude hypoxia during gestation suppresses large conductance $\mathrm{Ca}^{2+}$-activated $\mathrm{K}^{+}$channel function in uterine arteries: A causal role for microRNA-210. J. Physiol. 2018, 596, 5891-5906. [CrossRef] 
56. Noack, F.; Ribbat-Idel, J.; Thorns, C.; Chiriac, A.; Axt-Fliedner, R.; Diedrich, K.; Feller, A.C. miRNA expression profiling in formalin-fixed and paraffin-embedded placental tissue samples from pregnancies with severe preeclampsia. J. Perinat. Med. 2011, 39, 267-271. [CrossRef]

57. Timofeeva, A.V.; Gusar, V.A.; Kan, N.E.; Prozorovskaya, K.N.; Karapetyan, A.O.; Bayev, O.R.; Chagovets, V.V.; Kliver, S.F.; Iakovishina, D.Y.; Frankevich, V.E.; et al. Identification of potential early biomarkers of preeclampsia. Placenta 2018, 61, 61-71. [CrossRef]

58. Dai, X.; Cai, Y. Down-regulation of microRNA let-7d inhibits the proliferation and invasion of trophoblast cells in preeclampsia. J. Cell. Biochem. 2018, 119, 1141-1151. [CrossRef]

59. Wang, N.; Li, R.; Xue, M. Potential regulatory network in the PSG10P/miR-19a-3p/IL1RAP pathway is possibly involved in preeclampsia pathogenesis. J. Cell. Mol. Med. 2019, 23, 852-864. [CrossRef]

60. Kumar, P.; Luo, Y.; Tudela, C.; Alexander, J.M.; Mendelson, C.R. The c-Myc-regulated microRNA-17 92 (miR-17 92) and miR-106a 363 clusters target hCYP19A1 and hGCM1 to inhibit human trophoblast differentiation. Mol. Cell. Biol. 2013, 33, 1782-1796. [CrossRef]

61. Lou, C.X.; Zhou, X.T.; Tian, Q.C.; Xie, H.Q.; Zhang, J.Y. Low expression of microRNA-21 inhibits trophoblast cell infiltration through targeting PTEN. Eur. Rev. Med. Pharmacol. Sci. 2018, 22, 6181-6189. [CrossRef] [PubMed]

62. Wang, Y.; Zhang, Y.; Wang, H.; Wang, J.; Zhang, Y.; Wang, Y.; Pan, Z.; Luo, S. Aberrantly up-regulated miR-20a in pre-eclampsic placenta compromised the proliferative and invasive behaviors of trophoblast cells by targeting forkhead box protein A1. Int. J. Biol. Sci. 2014, 10, 973-982. [CrossRef] [PubMed]

63. Zhou, X.; Li, Q.; Xu, J.; Zhang, X.; Zhang, H.; Xiang, Y.; Fang, C.; Wang, T.; Xia, S.; Zhang, Q.; et al. The aberrantly expressed miR-193b-3p contributes to preeclampsia through regulating transforming growth factor-beta signaling. Sci. Rep. 2016, 6, 19910. [CrossRef] [PubMed]

64. Zou, Y.; Jiang, Z.; Yu, X.; Zhang, Y.; Sun, M.; Wang, W.; Ge, Z.; De, W.; Sun, L. MiR-101 regulates apoptosis of trophoblast HTR-8/SVneo cells by targeting endoplasmic reticulum (ER) protein 44 during preeclampsia. J. Hum. Hypertens. 2014, 28, 610-616. [CrossRef]

65. Yan, T.; Liu, Y.; Cui, K.; Hu, B.; Wang, F.; Zou, L. MicroRNA-126 regulates EPCs function: Implications for a role of miR-126 in preeclampsia. J. Cell. Biochem. 2013, 114, 2148-2159. [CrossRef]

66. Hong, F.; Li, Y.; Xu, Y. Decreased placental miR-126 expression and vascular endothelial growth factor levels in patients with pre-eclampsia. J. Int. Med. Res. 2014, 42, 1243-1251. [CrossRef]

67. Li, P.; Guo, W.; Du, L.; Zhao, J.; Wang, Y.; Liu, L.; Hu, Y.; Hou, Y. microRNA-29b contributes to pre-eclampsia through its effects on apoptosis, invasion and angiogenesis of trophoblast cells. Clin. Sci. 2013, 124, $27-40$. [CrossRef]

68. Niu, Z.R.; Han, T.; Sun, X.L.; Luan, L.X.; Gou, W.L.; Zhu, X.M. MicroRNA-30a-3p is overexpressed in the placentas of patients with preeclampsia and affects trophoblast invasion and apoptosis by its effects on IGF-1. Am. J. Obstet. Gynecol. 2018, 218, 249. [CrossRef]

69. Sun, M.; Chen, H.; Liu, J.; Tong, C.; Meng, T. MicroRNA-34a inhibits human trophoblast cell invasion by targeting MYC. BMC Cell Biol. 2015, 16, 21. [CrossRef]

70. Guo, M.; Zhao, X.; Yuan, X.; Li, P. Elevated microRNA-34a contributes to trophoblast cell apoptosis in preeclampsia by targeting BCL-2. J. Hum. Hypertens. 2017, 31, 815-820. [CrossRef]

71. Xue, F.; Yang, J.; Li, Q.; Zhou, H. Down-regulation of microRNA-34a-5p promotes trophoblast cell migration and invasion via targetting Smad4. Biosci. Rep. 2019, 39. [CrossRef] [PubMed]

72. Xiao, J.; Tao, T.; Yin, Y.; Zhao, L.; Yang, L.; Hu, L. miR-144 may regulate the proliferation, migration and invasion of trophoblastic cells through targeting PTEN in preeclampsia. Biomed. Pharmacother. 2017, 94, 341-353. [CrossRef] [PubMed]

73. Hu, S.; Li, J.; Tong, M.; Li, Q.; Chen, Y.; Lu, H.; Wang, Y.; Min, L. MicroRNA1443p may participate in the pathogenesis of preeclampsia by targeting Cox2. Mol. Med. Rep. 2019, 19, 4655-4662. [CrossRef] [PubMed]

74. Guo, L.; Tsai, S.Q.; Hardison, N.E.; James, A.H.; Motsinger-Reif, A.A.; Thames, B.; Stone, E.A.; Deng, C.; Piedrahita, J.A. Differentially expressed microRNAs and affected biological pathways revealed by modulated modularity clustering (MMC) analysis of human preeclamptic and IUGR placentas. Placenta 2013, 34, 599-605. [CrossRef]

75. Xiaobo, Z.; Qizhi, H.; Zhiping, W.; Tao, D. Down-regulated miR-149-5p contributes to preeclampsia via modulating endoglin expression. Pregnancy Hypertens. 2019, 15, 201-208. [CrossRef] 
76. Li, Q.; Pan, Z.; Wang, X.; Gao, Z.; Ren, C.; Yang, W. miR-125b-1-3p inhibits trophoblast cell invasion by targeting sphingosine-1-phosphate receptor 1 in preeclampsia. Biochem. Biophys. Res. Commun. 2014, 453, 57-63. [CrossRef]

77. Lu, T.M.; Lu, W.; Zhao, L.J. MicroRNA-137 Affects Proliferation and Migration of Placenta Trophoblast Cells in Preeclampsia by Targeting ERRalpha. Reprod. Sci. 2017, 24, 85-96. [CrossRef]

78. Ospina-Prieto, S.; Chaiwangyen, W.; Herrmann, J.; Groten, T.; Schleussner, E.; Markert, U.R.; Morales-Prieto, D.M. MicroRNA-141 is upregulated in preeclamptic placentae and regulates trophoblast invasion and intercellular communication. Transl. Res. 2016, 172, 61-72. [CrossRef]

79. Brkic, J.; Dunk, C.; O’Brien, J.; Fu, G.; Nadeem, L.; Wang, Y.L.; Rosman, D.; Salem, M.; Shynlova, O.; Yougbare, I.; et al. MicroRNA-218-5p Promotes Endovascular Trophoblast Differentiation and Spiral Artery Remodeling. Mol. Ther. 2018, 26, 2189-2205. [CrossRef]

80. Liu, E.; Liu, Z.; Zhou, Y.; Chen, M.; Wang, L.; Li, J. MicroRNA1423p inhibits trophoblast cell migration and invasion by disrupting the TGFbeta1/Smad3 signaling pathway. Mol. Med. Rep. 2019, 19, 3775-3782. [CrossRef]

81. Yang, Y.; Li, H.; Ma, Y.; Zhu, X.; Zhang, S.; Li, J. MiR-221-3p is down-regulated in preeclampsia and affects trophoblast growth, invasion and migration partly via targeting thrombospondin 2. Biomed. Pharmacother. 2019, 109, 127-134. [CrossRef] [PubMed]

82. Weedon-Fekjaer, M.S.; Sheng, Y.; Sugulle, M.; Johnsen, G.M.; Herse, F.; Redman, C.W.; Lyle, R.; Dechend, R.; Staff, A.C. Placental miR-1301 is dysregulated in early-onset preeclampsia and inversely correlated with maternal circulating leptin. Placenta 2014, 35, 709-717. [CrossRef] [PubMed]

83. Lazar, L.; Nagy, B.; Molvarec, A.; Szarka, A.; Rigo, J., Jr. Role of hsa-miR-325 in the etiopathology of preeclampsia. Mol. Med. Rep. 2012, 6, 597-600. [CrossRef] [PubMed]

84. Li, X.; Li, C.; Dong, X.; Gou, W. MicroRNA-155 inhibits migration of trophoblast cells and contributes to the pathogenesis of severe preeclampsia by regulating endothelial nitric oxide synthase. Mol. Med. Rep. 2014, 10, 550-554. [CrossRef] [PubMed]

85. Tsai, P.Y.; Li, S.H.; Chen, W.N.; Tsai, H.L.; Su, M.T. Differential miR-346 and miR-582-3p Expression in Association with Selected Maternal and Fetal Complications. Int. J. Mol. Sci. 2017, 18, 1570. [CrossRef] [PubMed]

86. Huang, X.; Wu, L.; Zhang, G.; Tang, R.; Zhou, X. Elevated MicroRNA-181a-5p Contributes to Trophoblast Dysfunction and Preeclampsia. Reprod. Sci. 2019, 26, 1121-1129. [CrossRef]

87. Fang, Y.N.; Huang, Z.L.; Li, H.; Tan, W.B.; Zhang, Q.G.; Wang, L.; Wu, J.L. Highly expressed miR-182-5p can promote preeclampsia progression by degrading RND3 and inhibiting HTR-8/SVneo cell invasion. Eur. Rev. Med. Pharmacol. Sci. 2018, 22, 6583-6590. [CrossRef]

88. Bai, Y.; Yang, W.; Yang, H.X.; Liao, Q.; Ye, G.; Fu, G.; Ji, L.; Xu, P.; Wang, H.; Li, Y.X.; et al. Downregulated miR-195 detected in preeclamptic placenta affects trophoblast cell invasion via modulating ActRIIA expression. PLoS ONE 2012, 7, e38875. [CrossRef]

89. Wang, F.; Yan, J. MicroRNA-454 is involved in regulating trophoblast cell proliferation, apoptosis, and invasion in preeclampsia by modulating the expression of ephrin receptor B4. Biomed. Pharmacother. 2018, 107, 746-753. [CrossRef]

90. Shi, Z.; She, K.; Li,H.; Yuan, X.; Han, X.; Wang, Y. MicroRNA-454 contributes to sustaining the proliferation and invasion of trophoblast cells through inhibiting Nodal/ALK7 signaling in pre-eclampsia. Chem. Biol. Interact. 2019, 298, 8-14. [CrossRef]

91. Lalevee, S.; Lapaire, O.; Buhler, M. miR455 is linked to hypoxia signaling and is deregulated in preeclampsia. Cell Death Dis. 2014, 5, e1408. [CrossRef] [PubMed]

92. Singh, K.; Williams, J., III; Brown, J.; Wang, E.T.; Lee, B.; Gonzalez, T.L.; Cui, J.; Goodarzi, M.O.; Pisarska, M.D. Up-regulation of microRNA-202-3p in first trimester placenta of pregnancies destined to develop severe preeclampsia, a pilot study. Pregnancy Hypertens. 2017, 10, 7-9. [CrossRef] [PubMed]

93. Zhang, M.; Muralimanoharan, S.; Wortman, A.C.; Mendelson, C.R. Primate-specific miR-515 family members inhibit key genes in human trophoblast differentiation and are upregulated in preeclampsia. Proc. Natl. Acad. Sci. USA 2016, 113, E7069-E7076. [CrossRef] [PubMed]

94. Liu, F.; Wu, K.; Wu, W.; Chen, Y.; Wu, H.; Wang, H.; Zhang, W. miR203 contributes to preeclampsia via inhibition of VEGFA expression. Mol. Med. Rep. 2018, 17, 5627-5634. [CrossRef] [PubMed] 
95. Lee, D.C.; Romero, R.; Kim, J.S.; Tarca, A.L.; Montenegro, D.; Pineles, B.L.; Kim, E.; Lee, J.; Kim, S.Y.; Draghici, S.; et al. miR-210 targets iron-sulfur cluster scaffold homologue in human trophoblast cell lines: Siderosis of interstitial trophoblasts as a novel pathology of preterm preeclampsia and small-for-gestational-age pregnancies. Am. J. Pathol. 2011, 179, 590-602. [CrossRef]

96. Luo, R.; Shao, X.; Xu, P.; Liu, Y.; Wang, Y.; Zhao, Y.; Liu, M.; Ji, L.; Li, Y.X.; Chang, C.; et al. MicroRNA-210 contributes to preeclampsia by downregulating potassium channel modulatory factor 1. Hypertension 2014, 64, 839-845. [CrossRef]

97. Wang, R.; Liu, W.; Liu, X.; Liu, X.; Tao, H.; Wu, D.; Zhao, Y.; Zou, L. MicroRNA-210 regulates human trophoblast cell line HTR-8/SVneo function by attenuating Notch1 expression: Implications for the role of microRNA-210 in pre-eclampsia. Mol. Reprod. Dev. 2019, 86, 896-907. [CrossRef]

98. Luo, R.; Wang, Y.; Xu, P.; Cao, G.; Zhao, Y.; Shao, X.; Li, Y.X.; Chang, C.; Peng, C.; Wang, Y.L. Hypoxia-inducible miR-210 contributes to preeclampsia via targeting thrombospondin type I domain containing 7A. Sci. Rep. 2016, 6, 19588. [CrossRef]

99. Adel, S.; Mansour, A.; Louka, M.; Matboli, M.; Elmekkawi, S.F.; Swelam, N. Evaluation of MicroRNA-210 and Protein tyrosine phosphatase, non-receptor type 2 in Pre-eclampsia. Gene 2017, 596, 105-109. [CrossRef]

100. Muralimanoharan, S.; Maloyan, A.; Mele, J.; Guo, C.; Myatt, L.G.; Myatt, L. MIR-210 modulates mitochondrial respiration in placenta with preeclampsia. Placenta 2012, 33, 816-823. [CrossRef]

101. Fang, M.; Du, H.; Han, B.; Xia, G.; Shi, X.; Zhang, F.; Fu, Q.; Zhang, T. Hypoxia-inducible microRNA-218 inhibits trophoblast invasion by targeting LASP1: Implications for preeclampsia development. Int. J. Biochem. Cell Biol. 2017, 87, 95-103. [CrossRef] [PubMed]

102. Gao, Y.; She, R.; Wang, Q.; Li, Y.; Zhang, H. Up-regulation of miR-299 suppressed the invasion and migration of HTR-8/SVneo trophoblast cells partly via targeting HDAC2 in pre-eclampsia. Biomed. Pharmacother. 2018, 97, 1222-1228. [CrossRef] [PubMed]

103. Gao, T.; Deng, M.; Wang, Q. MiRNA-320a inhibits trophoblast cell invasion by targeting estrogen-related receptor-gamma. J. Obstet. Gynaecol. Res. 2018, 44, 756-763. [CrossRef] [PubMed]

104. Wang, N.; Feng, Y.; Xu, J.; Zou, J.; Chen, M.; He, Y.; Liu, H.; Xue, M.; Gu, Y. miR-362-3p regulates cell proliferation, migration and invasion of trophoblastic cells under hypoxia through targeting Pax3. Biomed. Pharmacother. 2018, 99, 462-468. [CrossRef]

105. Yang, X.; Meng, T. MicroRNA-431 affects trophoblast migration and invasion by targeting ZEB1 in preeclampsia. Gene 2019, 683, 225-232. [CrossRef]

106. Fu, J.Y.; Xiao, Y.P.; Ren, C.L.; Guo, Y.W.; Qu, D.H.; Zhang, J.H.; Zhu, Y.J. Up-regulation of miR-517-5p inhibits ERK/MMP-2 pathway: Potential role in preeclampsia. Eur. Rev. Med. Pharmacol. Sci. 2018, 22, 6599-6608. [CrossRef]

107. Anton, L.; Olarerin-George, A.O.; Hogenesch, J.B.; Elovitz, M.A. Placental expression of miR-517a/b and miR-517c contributes to trophoblast dysfunction and preeclampsia. PLoS ONE 2015, 10, e0122707. [CrossRef]

108. Shi, Z.; Liu, B.; Li, Y.; Liu, F.; Yuan, X.; Wang, Y. MicroRNA-652-3p promotes the proliferation and invasion of the trophoblast HTR-8/SVneo cell line by targeting homeobox A9 to modulate the expression of ephrin receptor B4. Clin. Exp. Pharmacol. Physiol. 2019, 46, 587-596. [CrossRef]

109. Gao, W.L.; Liu, M.; Yang, Y.; Yang, H.; Liao, Q.; Bai, Y.; Li, Y.X.; Li, D.; Peng, C.; Wang, Y.L. The imprinted H19 gene regulates human placental trophoblast cell proliferation via encoding miR-675 that targets Nodal Modulator 1 (NOMO1). RNA Biol. 2012, 9, 1002-1010. [CrossRef]

110. Ding, J.; Huang, F.; Wu, G.; Han, T.; Xu, F.; Weng, D.; Wu, C.; Zhang, X.; Yao, Y.; Zhu, X. MiR-519d-3p suppresses invasion and migration of trophoblast cells via targeting MMP-2. PLoS ONE 2015, 10, e0120321. [CrossRef]

111. Jiang, L.; Long, A.; Tan, L.; Hong, M.; Wu, J.; Cai, L.; Li, Q. Elevated microRNA-520g in pre-eclampsia inhibits migration and invasion of trophoblasts. Placenta 2017, 51, 70-75. [CrossRef] [PubMed]

112. Tang, Q.; Wu, W.; Xu, X.; Huang, L.; Gao, Q.; Chen, H.; Sun, H.; Xia, Y.; Sha, J.; Wang, X.; et al. miR-141 contributes to fetal growth restriction by regulating PLAG1 expression. PLoS ONE 2013, 8, e58737. [CrossRef] [PubMed]

113. Maccani, M.A.; Padbury, J.F.; Marsit, C.J. miR-16 and miR-21 expression in the placenta is associated with fetal growth. PLoS ONE 2011, 6, e21210. [CrossRef] [PubMed] 
114. Cindrova-Davies, T.; Herrera, E.A.; Niu, Y.; Kingdom, J.; Giussani, D.A.; Burton, G.J. Reduced cystathionine gamma-lyase and increased miR-21 expression are associated with increased vascular resistance in growth-restricted pregnancies: Hydrogen sulfide as a placental vasodilator. Am. J. Pathol. 2013, 182, 1448-1458. [CrossRef] [PubMed]

115. Li, L.; Huang, X.; He, Z.; Xiong, Y.; Fang, Q. miRNA-210-3p regulates trophoblast proliferation and invasiveness through fibroblast growth factor 1 in selective intrauterine growth restriction. J. Cell. Mol. Med. 2019, 23, 4422-4433. [CrossRef]

116. Huang, L.; Shen, Z.; Xu, Q.; Huang, X.; Chen, Q.; Li, D. Increased levels of microRNA-424 are associated with the pathogenesis of fetal growth restriction. Placenta 2013, 34, 624-627. [CrossRef]

117. Wang, D.; Na, Q.; Song, W.W.; Song, G.Y. Altered Expression of miR-518b and miR-519a in the placenta is associated with low fetal birth weight. Am. J. Perinatol. 2014, 31, 729-734. [CrossRef]

118. Ducsay, C.A.; Goyal, R.; Pearce, W.J.; Wilson, S.; Hu, X.Q.; Zhang, L. Gestational Hypoxia and Developmental Plasticity. Physiol. Rev. 2018, 98, 1241-1334. [CrossRef]

119. Annibale, D.J.; Rosenfeld, C.R.; Stull, J.T.; Kamm, K.E. Protein content and myosin light chain phosphorylation in uterine arteries during pregnancy. Am. J. Physiol. 1990, 259, C484-C489. [CrossRef]

120. Griendling, K.K.; Fuller, E.O.; Cox, R.H. Pregnancy-induced changes in sheep uterine and carotid arteries. Am. J. Physiol. 1985, 248, H658-H665. [CrossRef]

121. Guenther, A.E.; Conley, A.J.; Van Orden, D.E.; Farley, D.B.; Ford, S.P. Structural and mechanical changes of uterine arteries during pregnancy in the pig. J. Anim. Sci. 1988, 66, 3144-3152. [CrossRef] [PubMed]

122. Osol, G.; Cipolla, M. Pregnancy-induced changes in the three-dimensional mechanical properties of pressurized rat uteroplacental (radial) arteries. Am. J. Obstet. Gynecol. 1993, 168, 268-274. [CrossRef]

123. Konje, J.C.; Kaufmann, P.; Bell, S.C.; Taylor, D.J. A longitudinal study of quantitative uterine blood flow with the use of color power angiography in appropriate for gestational age pregnancies. Am. J. Obstet. Gynecol. 2001, 185, 608-613. [CrossRef] [PubMed]

124. St-Louis, J.; Sicotte, B.; Bedard, S.; Brochu, M. Blockade of angiotensin receptor subtypes in arcuate uterine artery of pregnant and postpartum rats. Hypertension 2001, 38, 1017-1023. [CrossRef] [PubMed]

125. Palmer, S.K.; Zamudio, S.; Coffin, C.; Parker, S.; Stamm, E.; Moore, L.G. Quantitative estimation of human uterine artery blood flow and pelvic blood flow redistribution in pregnancy. Obstet. Gynecol. 1992, 80, 1000-1006. [PubMed]

126. Rennie, M.Y.; Whiteley, K.J.; Adamson, S.L.; Sled, J.G. Quantification of Gestational Changes in the Uteroplacental Vascular Tree Reveals Vessel Specific Hemodynamic Roles During Pregnancy in Mice. Biol. Reprod. 2016, 95, 43. [CrossRef]

127. Osol, G.; Mandala, M. Maternal uterine vascular remodeling during pregnancy. Physiology 2009, $24,58-71$. [CrossRef]

128. Kaufmann, P.; Black, S.; Huppertz, B. Endovascular trophoblast invasion: Implications for the pathogenesis of intrauterine growth retardation and preeclampsia. Biol. Reprod. 2003, 69, 1-7. [CrossRef]

129. Lyall, F. Priming and remodelling of human placental bed spiral arteries during pregnancy-A review. Placenta 2005, 26, S31-S36. [CrossRef]

130. Pijnenborg, R.; Bland, J.M.; Robertson, W.B.; Brosens, I. Uteroplacental arterial changes related to interstitial trophoblast migration in early human pregnancy. Placenta 1983, 4, 397-413. [CrossRef]

131. Kam, E.P.; Gardner, L.; Loke, Y.W.; King, A. The role of trophoblast in the physiological change in decidual spiral arteries. Hum. Reprod. 1999, 14, 2131-2138. [CrossRef] [PubMed]

132. Ashton, S.V.; Whitley, G.S.; Dash, P.R.; Wareing, M.; Crocker, I.P.; Baker, P.N.; Cartwright, J.E. Uterine spiral artery remodeling involves endothelial apoptosis induced by extravillous trophoblasts through Fas/FasL interactions. Arterioscler. Thromb. Vasc. Biol. 2005, 25, 102-108. [CrossRef] [PubMed]

133. Keogh, R.J.; Harris, L.K.; Freeman, A.; Baker, P.N.; Aplin, J.D.; Whitley, G.S.; Cartwright, J.E. Fetal-derived trophoblast use the apoptotic cytokine tumor necrosis factor-alpha-related apoptosis-inducing ligand to induce smooth muscle cell death. Circ. Res. 2007, 100, 834-841. [CrossRef] [PubMed]

134. Whitley, G.S.; Cartwright, J.E. Trophoblast-mediated spiral artery remodelling: A role for apoptosis. J. Anat. 2009, 215, 21-26. [CrossRef] [PubMed]

135. Zhou, Y.; Damsky, C.H.; Fisher, S.J. Preeclampsia is associated with failure of human cytotrophoblasts to mimic a vascular adhesion phenotype. One cause of defective endovascular invasion in this syndrome? J. Clin. Investig. 1997, 99, 2152-2164. [CrossRef] 
136. Bulmer, J.N.; Innes, B.A.; Levey, J.; Robson, S.C.; Lash, G.E. The role of vascular smooth muscle cell apoptosis and migration during uterine spiral artery remodeling in normal human pregnancy. FASEB J. 2012, 26, 2975-2985. [CrossRef]

137. Burton, G.J.; Woods, A.W.; Jauniaux, E.; Kingdom, J.C. Rheological and physiological consequences of conversion of the maternal spiral arteries for uteroplacental blood flow during human pregnancy. Placenta 2009, 30, 473-482. [CrossRef]

138. Chang, K.; Lubo, Z. Review article: Steroid hormones and uterine vascular adaptation to pregnancy. Reprod. Sci. 2008, 15, 336-348. [CrossRef]

139. Pastore, M.B.; Jobe, S.O.; Ramadoss, J.; Magness, R.R. Estrogen receptor-alpha and estrogen receptor-beta in the uterine vascular endothelium during pregnancy: Functional implications for regulating uterine blood flow. Semin. Reprod. Med. 2012, 30, 46-61. [CrossRef]

140. Chatuphonprasert, W.; Jarukamjorn, K.; Ellinger, I. Physiology and Pathophysiology of Steroid Biosynthesis, Transport and Metabolism in the Human Placenta. Front. Pharmacol. 2018, 9, 1027. [CrossRef]

141. Berkane, N.; Liere, P.; Oudinet, J.P.; Hertig, A.; Lefevre, G.; Pluchino, N.; Schumacher, M.; Chabbert-Buffet, N. From Pregnancy to Preeclampsia: A Key Role for Estrogens. Endocr. Rev. 2017, 38, 123-144. [CrossRef] [PubMed]

142. Rosenfeld, C.R.; Morriss, F.H., Jr.; Makowski, E.L.; Meschia, G.; Battaglia, F.C. Circulatory changes in the reproductive tissues of ewes during pregnancy. Gynecol. Investig. 1974, 5, 252-268. [CrossRef]

143. Magness, R.R.; Phernetton, T.M.; Gibson, T.C.; Chen, D.B. Uterine blood flow responses to ICI 182780 in ovariectomized oestradiol-17beta-treated, intact follicular and pregnant sheep. J. Physiol. 2005, 565, 71-83. [CrossRef] [PubMed]

144. Magness, R.R.; Phernetton, T.M.; Zheng, J. Systemic and uterine blood flow distribution during prolonged infusion of 17beta-estradiol. Am. J. Physiol. 1998, 275, H731-H743. [CrossRef] [PubMed]

145. Xiao, D.; Huang, X.; Yang, S.; Zhang, L. Direct chronic effect of steroid hormones in attenuating uterine arterial myogenic tone: Role of protein kinase c/extracellular signal-regulated kinase 1/2. Hypertension 2009, 54, 352-358. [CrossRef]

146. Magness, R.R.; Rosenfeld, C.R. Local and systemic estradiol-17 beta: Effects on uterine and systemic vasodilation. Am. J. Physiol. 1989, 256, E536-E542. [CrossRef]

147. Corcoran, J.J.; Nicholson, C.; Sweeney, M.; Charnock, J.C.; Robson, S.C.; Westwood, M.; Taggart, M.J. Human uterine and placental arteries exhibit tissue-specific acute responses to 17beta-estradiol and estrogen-receptor-specific agonists. Mol. Hum. Reprod. 2014, 20, 433-441. [CrossRef]

148. Rosenfeld, C.R.; White, R.E.; Roy, T.; Cox, B.E. Calcium-activated potassium channels and nitric oxide coregulate estrogen-induced vasodilation. Am. J. Physiol. Heart Circ. Physiol. 2000, 279, H319-H328. [CrossRef]

149. Tropea, T.; De Francesco, E.M.; Rigiracciolo, D.; Maggiolini, M.; Wareing, M.; Osol, G.; Mandala, M. Pregnancy Augments G Protein Estrogen Receptor (GPER) Induced Vasodilation in Rat Uterine Arteries via the Nitric Oxide-cGMP Signaling Pathway. PLoS ONE 2015, 10, e0141997. [CrossRef]

150. Rupnow, H.L.; Phernetton, T.M.; Shaw, C.E.; Modrick, M.L.; Bird, I.M.; Magness, R.R. Endothelial vasodilator production by uterine and systemic arteries. VII. Estrogen and progesterone effects on eNOS. Am. J. Physiol. Heart Circ. Physiol. 2001, 280, H1699-H1705. [CrossRef]

151. Rosenfeld, C.R.; Chen, C.; Roy, T.; Liu, X. Estrogen selectively up-regulates eNOS and nNOS in reproductive arteries by transcriptional mechanisms. J. Soc. Gynecol. Investig. 2003, 10, 205-215. [CrossRef] [PubMed]

152. Nagar, D.; Liu, X.T.; Rosenfeld, C.R. Estrogen regulates $\left\{\right.$ beta\}1-subunit expression in $\mathrm{Ca}^{2+}$-activated $\mathrm{K}^{+}$ channels in arteries from reproductive tissues. Am. J. Physiol. Heart Circ. Physiol. 2005, 289, H1417-H1427. [CrossRef] [PubMed]

153. Hu, X.Q.; Xiao, D.; Zhu, R.; Huang, X.; Yang, S.; Wilson, S.; Zhang, L. Pregnancy upregulates large-conductance $\mathrm{Ca}^{2+}$-activated $\mathrm{K}^{+}$channel activity and attenuates myogenic tone in uterine arteries. Hypertension 2011, 58, 1132-1139. [CrossRef] [PubMed]

154. Chen, M.; Dasgupta, C.; Xiong, F.; Zhang, L. Epigenetic upregulation of large-conductance $\mathrm{Ca}^{2+}$-activated $\mathrm{K}^{+}$ channel expression in uterine vascular adaptation to pregnancy. Hypertension 2014, 64, 610-618. [CrossRef]

155. Lechuga, T.J.; Bilg, A.K.; Patel, B.A.; Nguyen, N.A.; Qi, Q.R.; Chen, D.B. Estradiol-17beta stimulates H2 S biosynthesis by ER-dependent CBS and CSE transcription in uterine artery smooth muscle cells in vitro. J. Cell. Physiol. 2019, 234, 9264-9273. [CrossRef] 
156. Rosenfeld, C.R.; Cox, B.E.; Roy, T.; Magness, R.R. Nitric oxide contributes to estrogen-induced vasodilation of the ovine uterine circulation. J. Clin. Investig. 1996, 98, 2158-2166. [CrossRef]

157. Kublickiene, K.R.; Kublickas, M.; Lindblom, B.; Lunell, N.O.; Nisell, H. A comparison of myogenic and endothelial properties of myometrial and omental resistance vessels in late pregnancy. Am. J. Obstet. Gynecol. 1997, 176, 560-566. [CrossRef]

158. Gokina, N.I.; Kuzina, O.Y.; Fuller, R.; Osol, G. Local uteroplacental influences are responsible for the induction of uterine artery myogenic tone during rat pregnancy. Reprod. Sci. 2009, 16, 1072-1081. [CrossRef]

159. Rosenfeld, C.R. Mechanisms regulating angiotensin II responsiveness by the uteroplacental circulation. Am. J. Physiol. Regul. Integr. Comp. Physiol. 2001, 281, R1025-R1040. [CrossRef]

160. Weiner, C.P.; Thompson, L.P.; Liu, K.Z.; Herrig, J.E. Pregnancy reduces serotonin-induced contraction of guinea pig uterine and carotid arteries. Am. J. Physiol. 1992, 263, H1764-H1769. [CrossRef]

161. Weiner, C.; Liu, K.Z.; Thompson, L.; Herrig, J.; Chestnut, D. Effect of pregnancy on endothelium and smooth muscle: Their role in reduced adrenergic sensitivity. Am. J. Physiol. 1991, 261, H1275-H1283. [CrossRef] [PubMed]

162. Ni, Y.; Meyer, M.; Osol, G. Gestation increases nitric oxide-mediated vasodilation in rat uterine arteries. Am. J. Obstet. Gynecol. 1997, 176, 856-864. [CrossRef]

163. Ni, Y.; May, V.; Braas, K.; Osol, G. Pregnancy augments uteroplacental vascular endothelial growth factor gene expression and vasodilator effects. Am. J. Physiol. 1997, 273, H938-H944. [CrossRef] [PubMed]

164. Nelson, S.H.; Steinsland, O.S.; Suresh, M.S.; Lee, N.M. Pregnancy augments nitric oxide-dependent dilator response to acetylcholine in the human uterine artery. Hum. Reprod. 1998, 13, 1361-1367. [CrossRef]

165. Xiao, D.; Pearce, W.J.; Zhang, L. Pregnancy enhances endothelium-dependent relaxation of ovine uterine artery: Role of $\mathrm{NO}$ and intracellular $\mathrm{Ca}^{2+}$. Am. J. Physiol. Heart Circ. Physiol. 2001, 281, H183-H190. [CrossRef]

166. Cooke, C.L.; Davidge, S.T. Pregnancy-induced alterations of vascular function in mouse mesenteric and uterine arteries. Biol. Reprod. 2003, 68, 1072-1077. [CrossRef]

167. Gokina, N.I.; Kuzina, O.Y.; Vance, A.M. Augmented EDHF signaling in rat uteroplacental vasculature during late pregnancy. Am. J. Physiol. Heart Circ. Physiol. 2010, 299, H1642-H1652. [CrossRef]

168. Lechuga, T.J.; Qi, Q.R.; Magness, R.R.; Chen, D.B. Ovine uterine artery hydrogen sulfide biosynthesis in vivo: Effects of ovarian cycle and pregnancydagger. Biol. Reprod. 2019, 100, 1630-1636. [CrossRef]

169. Jaggar, J.H.; Wellman, G.C.; Heppner, T.J.; Porter, V.A.; Perez, G.J.; Gollasch, M.; Kleppisch, T.; Rubart, M.; Stevenson, A.S.; Lederer, W.J.; et al. $\mathrm{Ca}^{2+}$ channels, ryanodine receptors and $\mathrm{Ca}^{2+}$-activated $\mathrm{K}+$ channels: A functional unit for regulating arterial tone. Acta Physiol. Scand. 1998, 164, 577-587. [CrossRef]

170. Veerareddy, S.; Cooke, C.L.; Baker, P.N.; Davidge, S.T. Vascular adaptations to pregnancy in mice: Effects on myogenic tone. Am. J. Physiol. Heart Circ. Physiol. 2002, 283, H2226-H2233. [CrossRef]

171. Xiao, D.; Buchholz, J.N.; Zhang, L. Pregnancy attenuates uterine artery pressure-dependent vascular tone: Role of PKC/ERK pathway. Am. J. Physiol. Heart Circ. Physiol. 2006, 290, H2337-H2343. [CrossRef] [PubMed]

172. Hu, X.Q.; Xiao, D.; Zhu, R.; Huang, X.; Yang, S.; Wilson, S.M.; Zhang, L. Chronic hypoxia suppresses pregnancy-induced upregulation of large-conductance $\mathrm{Ca}^{2+}$-activated $\mathrm{K}^{+}$channel activity in uterine arteries. Hypertension 2012, 60, 214-222. [CrossRef] [PubMed]

173. Hu, X.Q.; Song, R.; Romero, M.; Dasgupta, C.; Huang, X.; Holguin, M.A.; Williams, V.; Xiao, D.; Wilson, S.M.; Zhang, L. Pregnancy Increases $\mathrm{Ca}^{2+}$ Sparks/Spontaneous Transient Outward Currents and Reduces Uterine Arterial Myogenic Tone. Hypertension 2019, 73, 691-702. [CrossRef] [PubMed]

174. Hu, X.Q.; Dasgupta, C.; Xiao, D.; Huang, X.; Yang, S.; Zhang, L. MicroRNA-210 Targets Ten-Eleven Translocation Methylcytosine Dioxygenase 1 and Suppresses Pregnancy-Mediated Adaptation of Large Conductance $\mathrm{Ca}^{2+}$-Activated $\mathrm{K}^{+}$Channel Expression and Function in Ovine Uterine Arteries. Hypertension 2017, 70, 601-612. [CrossRef] [PubMed]

175. Rosenfeld, C.R.; Cornfield, D.N.; Roy, T. $\mathrm{Ca}^{2+}$-activated $\mathrm{K}^{+}$channels modulate basal and E(2)beta-induced rises in uterine blood flow in ovine pregnancy. Am. J. Physiol. Heart Circ. Physiol. 2001, 281, H422-H431. [CrossRef] [PubMed]

176. Rosenfeld, C.R.; Roy, T.; DeSpain, K.; Cox, B.E. Large-conductance $\mathrm{Ca}^{2+}$-dependent $\mathrm{K}^{+}$channels regulate basal uteroplacental blood flow in ovine pregnancy. J. Soc. Gynecol. Investig. 2005, 12, 402-408. [CrossRef] [PubMed] 
177. Osol, G.; Cipolla, M. Interaction of myogenic and adrenergic mechanisms in isolated, pressurized uterine radial arteries from late-pregnant and nonpregnant rats. Am. J. Obstet. Gynecol. 1993, 168, 697-705. [CrossRef]

178. Eckman, D.M.; Gupta, R.; Rosenfeld, C.R.; Morgan, T.M.; Charles, S.M.; Mertz, H.; Moore, L.G. Pregnancy increases myometrial artery myogenic tone via NOS- or COX-independent mechanisms. Am. J. Physiol. Regul. Integr. Comp. Physiol. 2012, 303, R368-R375. [CrossRef]

179. Brosens, I.A.; Robertson, W.B.; Dixon, H.G. The role of the spiral arteries in the pathogenesis of pre-eclampsia. J. Pathol. 1970, 101, Pvi.

180. Gerretsen, G.; Huisjes, H.J.; Elema, J.D. Morphological changes of the spiral arteries in the placental bed in relation to pre-eclampsia and fetal growth retardation. Br. J. Obstet. Gynaecol. 1981, 88, 876-881. [CrossRef]

181. Meekins, J.W.; Pijnenborg, R.; Hanssens, M.; McFadyen, I.R.; van Asshe, A. A study of placental bed spiral arteries and trophoblast invasion in normal and severe pre-eclamptic pregnancies. Br. J. Obstet. Gynaecol. 1994, 101, 669-674. [CrossRef] [PubMed]

182. Kadyrov, M.; Kingdom, J.C.; Huppertz, B. Divergent trophoblast invasion and apoptosis in placental bed spiral arteries from pregnancies complicated by maternal anemia and early-onset preeclampsia/intrauterine growth restriction. Am. J. Obstet. Gynecol. 2006, 194, 557-563. [CrossRef] [PubMed]

183. Pijnenborg, R.; Anthony, J.; Davey, D.A.; Rees, A.; Tiltman, A.; Vercruysse, L.; van Assche, A. Placental bed spiral arteries in the hypertensive disorders of pregnancy. Br. J. Obstet. Gynaecol. 1991, 98, 648-655. [CrossRef] [PubMed]

184. Lyall, F.; Robson, S.C.; Bulmer, J.N. Spiral artery remodeling and trophoblast invasion in preeclampsia and fetal growth restriction: Relationship to clinical outcome. Hypertension 2013, 62, 1046-1054. [CrossRef]

185. Ong, S.S.; Baker, P.N.; Mayhew, T.M.; Dunn, W.R. Remodeling of myometrial radial arteries in preeclampsia. Am. J. Obstet. Gynecol. 2005, 192, 572-579. [CrossRef]

186. Van der Heijden, O.W.; Essers, Y.P.; Fazzi, G.; Peeters, L.L.; De Mey, J.G.; van Eys, G.J. Uterine artery remodeling and reproductive performance are impaired in endothelial nitric oxide synthase-deficient mice. Biol. Reprod. 2005, 72, 1161-1168. [CrossRef]

187. Rennie, M.Y.; Rahman, A.; Whiteley, K.J.; Sled, J.G.; Adamson, S.L. Site-specific increases in utero- and fetoplacental arterial vascular resistance in eNOS-deficient mice due to impaired arterial enlargement. Biol. Reprod. 2015, 92, 48. [CrossRef]

188. Leiberman, J.R.; Meizner, I.; Mazor, M.; Insler, V. Blood supply to the uterus in preeclampsia. Eur. J. Obstet. Gynecol. Reprod. Biol. 1988, 28, 23-27. [CrossRef]

189. Lunell, N.O.; Sarby, B.; Lewander, R.; Nylund, L. Comparison of uteroplacental blood flow in normal and in intrauterine growth-retarded pregnancy. Measurements with Indium-113m and a computer-linked gammacamera. Gynecol. Obstet. Investig. 1979, 10, 106-118. [CrossRef]

190. Lunell, N.O.; Nylund, L.E.; Lewander, R.; Sarby, B. Uteroplacental blood flow in pre-eclampsia measurements with indium-113m and a computer-linked gamma camera. Clin. Exp. Hypertens. Part B 1982, 1, 105-117. [CrossRef]

191. Takata, M.; Nakatsuka, M.; Kudo, T. Differential blood flow in uterine, ophthalmic, and brachial arteries of preeclamptic women. Obstet. Gynecol. 2002, 100, 931-939. [CrossRef] [PubMed]

192. Konje, J.C.; Howarth, E.S.; Kaufmann, P.; Taylor, D.J. Longitudinal quantification of uterine artery blood volume flow changes during gestation in pregnancies complicated by intrauterine growth restriction. BJOG 2003, 110, 301-305. [CrossRef] [PubMed]

193. Napolitano, R.; Rajakulasingam, R.; Memmo, A.; Bhide, A.; Thilaganathan, B. Uterine artery Doppler screening for pre-eclampsia: Comparison of the lower, mean and higher first-trimester pulsatility indices. Ultrasound Obstet. Gynecol. 2011, 37, 534-537. [CrossRef] [PubMed]

194. Gopalakrishnan, K.; Mishra, J.S.; Chinnathambi, V.; Vincent, K.L.; Patrikeev, I.; Motamedi, M.; Saade, G.R.; Hankins, G.D.; Sathishkumar, K. Elevated Testosterone Reduces Uterine Blood Flow, Spiral Artery Elongation, and Placental Oxygenation in Pregnant Rats. Hypertension 2016, 67, 630-639. [CrossRef] [PubMed]

195. Kublickiene, K.R.; Lindblom, B.; Kruger, K.; Nisell, H. Preeclampsia: Evidence for impaired shear stress-mediated nitric oxide release in uterine circulation. Am. J. Obstet. Gynecol. 2000, 183, 160-166. [CrossRef]

196. Chang, K.; Xiao, D.; Huang, X.; Xue, Z.; Yang, S.; Longo, L.D.; Zhang, L. Chronic hypoxia inhibits sex steroid hormone-mediated attenuation of ovine uterine arterial myogenic tone in pregnancy. Hypertension 2010, 56, 750-757. [CrossRef] [PubMed] 
197. Reho, J.J.; Toot, J.D.; Peck, J.; Novak, J.; Yun, Y.H.; Ramirez, R.J. Increased Myogenic Reactivity of Uterine Arteries from Pregnant Rats with Reduced Uterine Perfusion Pressure. Pregnancy Hypertens. 2012, 2, 106-114. [CrossRef]

198. Ashworth, J.R.; Warren, A.Y.; Baker, P.N.; Johnson, I.R. Loss of endothelium-dependent relaxation in myometrial resistance arteries in pre-eclampsia. Br. J. Obstet. Gynaecol. 1997, 104, 1152-1158. [CrossRef]

199. Ong, S.S.; Moore, R.J.; Warren, A.Y.; Crocker, I.P.; Fulford, J.; Tyler, D.J.; Gowland, P.A.; Baker, P.N. Myometrial and placental artery reactivity alone cannot explain reduced placental perfusion in pre-eclampsia and intrauterine growth restriction. BJOG 2003, 110, 909-915. [CrossRef]

200. Wimalasundera, R.C.; Thom, S.A.; Regan, L.; Hughes, A.D. Effects of vasoactive agents on intracellular calcium and force in myometrial and subcutaneous resistance arteries isolated from preeclamptic, pregnant, and nonpregnant woman. Am. J. Obstet. Gynecol. 2005, 192, 625-632. [CrossRef]

201. Luksha, L.; Luksha, N.; Kublickas, M.; Nisell, H.; Kublickiene, K. Diverse mechanisms of endothelium-derived hyperpolarizing factor-mediated dilatation in small myometrial arteries in normal human pregnancy and preeclampsia. Biol. Reprod. 2010, 83, 728-735. [CrossRef] [PubMed]

202. Zamudio, S. High-altitude hypoxia and preeclampsia. Front. Biosci. 2007, 12, 2967-2977. [CrossRef] [PubMed]

203. Moore, L.G.; Charles, S.M.; Julian, C.G. Humans at high altitude: Hypoxia and fetal growth. Respir. Physiol. Neurobiol. 2011, 178, 181-190. [CrossRef] [PubMed]

204. Tissot van Patot, M.; Grilli, A.; Chapman, P.; Broad, E.; Tyson, W.; Heller, D.S.; Zwerdlinger, L.; Zamudio, S. Remodelling of uteroplacental arteries is decreased in high altitude placentae. Placenta 2003, 24, 326-335. [CrossRef] [PubMed]

205. Lorca, R.A.; Lane, S.L.; Bales, E.S.; Nsier, H.; Yi, H.; Donnelly, M.A.; Euser, A.G.; Julian, C.G.; Moore, L.G. High Altitude Reduces NO-Dependent Myometrial Artery Vasodilator Response During Pregnancy. Hypertension 2019, 73, 1319-1326. [CrossRef]

206. Zamudio, S.; Palmer, S.K.; Droma, T.; Stamm, E.; Coffin, C.; Moore, L.G. Effect of altitude on uterine artery blood flow during normal pregnancy. J. Appl. Physiol. 1995, 79, 7-14. [CrossRef]

207. Julian, C.G.; Galan, H.L.; Wilson, M.J.; Desilva, W.; Cioffi-Ragan, D.; Schwartz, J.; Moore, L.G. Lower uterine artery blood flow and higher endothelin relative to nitric oxide metabolite levels are associated with reductions in birth weight at high altitude. Am. J. Physiol. Regul. Integr. Comp. Physiol. 2008, 295, R906-R915. [CrossRef]

208. Anderson, C.M.; Lopez, F.; Zhang, H.Y.; Pavlish, K.; Benoit, J.N. Reduced uteroplacental perfusion alters uterine arcuate artery function in the pregnant Sprague-Dawley rat. Biol. Reprod. 2005, 72, 762-766. [CrossRef]

209. Fitzgerald, J.S.; Busch, S.; Wengenmayer, T.; Foerster, K.; de la Motte, T.; Poehlmann, T.G.; Markert, U.R. Signal transduction in trophoblast invasion. Chem. Immunol. Allergy 2005, 88, 181-199. [CrossRef]

210. Gupta, S.K.; Malhotra, S.S.; Malik, A.; Verma, S.; Chaudhary, P. Cell Signaling Pathways Involved During Invasion and Syncytialization of Trophoblast Cells. Am. J. Reprod. Immunol. 2016, 75, 361-371. [CrossRef]

211. Morrison, D.K. MAP kinase pathways. Cold Spring Harb. Perspect. Biol. 2012, 4. [CrossRef] [PubMed]

212. Qiu, Q.; Yang, M.; Tsang, B.K.; Gruslin, A. Both mitogen-activated protein kinase and phosphatidylinositol 3-kinase signalling are required in epidermal growth factor-induced human trophoblast migration. Mol. Hum. Reprod. 2004, 10, 677-684. [CrossRef] [PubMed]

213. Malik, A.; Pal, R.; Gupta, S.K. Interdependence of JAK-STAT and MAPK signaling pathways during EGF-mediated HTR-8/SVneo cell invasion. PLoS ONE 2017, 12, e0178269. [CrossRef] [PubMed]

214. Suman, P.; Gupta, S.K. STAT3 and ERK1/2 cross-talk in leukaemia inhibitory factor mediated trophoblastic JEG-3 cell invasion and expression of mucin 1 and Fos. Am. J. Reprod. Immunol. 2014, 72, 65-74. [CrossRef] [PubMed]

215. Appel, S.; Ankerne, J.; Appel, J.; Oberthuer, A.; Mallmann, P.; Dotsch, J. CNN3 regulates trophoblast invasion and is upregulated by hypoxia in BeWo cells. PLoS ONE 2014, 9, e103216. [CrossRef] [PubMed]

216. LaMarca, H.L.; Dash, P.R.; Vishnuthevan, K.; Harvey, E.; Sullivan, D.E.; Morris, C.A.; Whitley, G.S. Epidermal growth factor-stimulated extravillous cytotrophoblast motility is mediated by the activation of PI3-K, Akt and both p38 and p42/44 mitogen-activated protein kinases. Hum. Reprod. 2008, 23, 1733-1741. [CrossRef] 
217. Cartwright, J.E.; Tse, W.K.; Whitley, G.S. Hepatocyte growth factor induced human trophoblast motility involves phosphatidylinositol-3-kinase, mitogen-activated protein kinase, and inducible nitric oxide synthase. Exp. Cell Res. 2002, 279, 219-226. [CrossRef]

218. Moon, K.C.; Park, J.S.; Norwitz, E.R.; Kim, D.I.; Oh, K.J.; Park, C.W.; Jun, J.K.; Syn, H.C. Expression of extracellular signal-regulated kinase1/2 and p38 mitogen-activated protein kinase in the invasive trophoblasts at the human placental bed. Placenta 2008, 29, 391-395. [CrossRef]

219. Wang, Y.; Cheng, K.; Zhou, W.; Liu, H.; Yang, T.; Hou, P.; Li, X. miR-141-5p regulate ATF2 via effecting MAPK1/ERK2 signaling to promote preeclampsia. Biomed. Pharmacother. 2019, 115, 108953. [CrossRef]

220. Webster, R.P.; Brockman, D.; Myatt, L. Nitration of p38 MAPK in the placenta: Association of nitration with reduced catalytic activity of p38 MAPK in pre-eclampsia. Mol. Hum. Reprod. 2006, 12, 677-685. [CrossRef]

221. Yang, Q.E.; Giassetti, M.I.; Ealy, A.D. Fibroblast growth factors activate mitogen-activated protein kinase pathways to promote migration in ovine trophoblast cells. Reproduction 2011, 141, 707-714. [CrossRef] [PubMed]

222. Mendelson, K.; Evans, T.; Hla, T. Sphingosine 1-phosphate signalling. Development 2014, 141, 5-9. [CrossRef] [PubMed]

223. Yang, W.; Li, Q.; Pan, Z. Sphingosine-1-phosphate promotes extravillous trophoblast cell invasion by activating MEK/ERK/MMP-2 signaling pathways via S1P/S1PR1 axis activation. PLoS ONE 2014, 9, e106725. [CrossRef] [PubMed]

224. Anton, L.; Olarerin-George, A.O.; Schwartz, N.; Srinivas, S.; Bastek, J.; Hogenesch, J.B.; Elovitz, M.A. miR-210 inhibits trophoblast invasion and is a serum biomarker for preeclampsia. Am. J. Pathol. 2013, 183, 1437-1445. [CrossRef]

225. Hemmings, B.A.; Restuccia, D.F. PI3K-PKB/Akt pathway. Cold Spring Harb. Perspect. Biol. 2012, 4, a011189. [CrossRef]

226. Tamguney, T.; Stokoe, D. New insights into PTEN. J. Cell Sci. 2007, 120, 4071-4079. [CrossRef]

227. Kent, L.N.; Rumi, M.A.; Kubota, K.; Lee, D.S.; Soares, M.J. FOSL1 is integral to establishing the maternal-fetal interface. Mol. Cell. Biol. 2011, 31, 4801-4813. [CrossRef]

228. Xu, Y.; Sui, L.; Qiu, B.; Yin, X.; Liu, J.; Zhang, X. ANXA4 promotes trophoblast invasion via the PI3K/Akt/eNOS pathway in preeclampsia. Am. J. Physiol. Cell Physiol. 2019, 316, C481-C491. [CrossRef]

229. Budi, E.H.; Duan, D.; Derynck, R. Transforming Growth Factor-beta Receptors and Smads: Regulatory Complexity and Functional Versatility. Trends Cell Biol. 2017, 27, 658-672. [CrossRef]

230. Feng, X.H.; Derynck, R. Specificity and versatility in tgf-beta signaling through Smads. Annu. Rev. Cell Dev. Biol. 2005, 21, 659-693. [CrossRef]

231. Lash, G.E.; Otun, H.A.; Innes, B.A.; Bulmer, J.N.; Searle, R.F.; Robson, S.C. Inhibition of trophoblast cell invasion by TGFB1, 2, and 3 is associated with a decrease in active proteases. Biol. Reprod. 2005, 73, 374-381. [CrossRef] [PubMed]

232. Zhao, M.R.; Qiu, W.; Li, Y.X.; Zhang, Z.B.; Li, D.; Wang, Y.L. Dual effect of transforming growth factor beta1 on cell adhesion and invasion in human placenta trophoblast cells. Reproduction 2006, 132, 333-341. [CrossRef] [PubMed]

233. Nadeem, L.; Munir, S.; Fu, G.; Dunk, C.; Baczyk, D.; Caniggia, I.; Lye, S.; Peng, C. Nodal signals through activin receptor-like kinase 7 to inhibit trophoblast migration and invasion: Implication in the pathogenesis of preeclampsia. Am. J. Pathol. 2011, 178, 1177-1189. [CrossRef] [PubMed]

234. Cheng, J.C.; Chang, H.M.; Leung, P.C. Transforming growth factor-beta1 inhibits trophoblast cell invasion by inducing Snail-mediated down-regulation of vascular endothelial-cadherin protein. J. Biol. Chem. 2013, 288, 33181-33192. [CrossRef]

235. Chauvin, S.; Yinon, Y.; Xu, J.; Ermini, L.; Sallais, J.; Tagliaferro, A.; Todros, T.; Post, M.; Caniggia, I. Aberrant TGFbeta Signalling Contributes to Dysregulation of Sphingolipid Metabolism in Intrauterine Growth Restriction. J. Clin. Endocrinol. Metab. 2015, 100, E986-E996. [CrossRef]

236. Wu, H.; Wang, H.; Liu, M.; Bai, Y.; Li, Y.X.; Ji, L.; Peng, C.; Yu, Y.; Wang, Y.L. MiR-195 participates in the placental disorder of preeclampsia via targeting activin receptor type-2B in trophoblastic cells. J. Hypertens. 2016, 34, 1371-1379. [CrossRef]

237. Mano, Y.; Kotani, T.; Shibata, K.; Matsumura, H.; Tsuda, H.; Sumigama, S.; Yamamoto, E.; Iwase, A.; Senga, T.; Kikkawa, F. The loss of endoglin promotes the invasion of extravillous trophoblasts. Endocrinology 2011, 152, 4386-4394. [CrossRef] 
238. Caniggia, I.; Taylor, C.V.; Ritchie, J.W.; Lye, S.J.; Letarte, M. Endoglin regulates trophoblast differentiation along the invasive pathway in human placental villous explants. Endocrinology 1997, 138, 4977-4988. [CrossRef]

239. Gu, Y.; Lewis, D.F.; Wang, Y. Placental productions and expressions of soluble endoglin, soluble fms-like tyrosine kinase receptor-1, and placental growth factor in normal and preeclamptic pregnancies. J. Clin. Endocrinol. Metab. 2008, 93, 260-266. [CrossRef]

240. Angers, S.; Moon, R.T. Proximal events in Wnt signal transduction. Nat. Rev. Mol. Cell Biol. 2009, 10, 468-477. [CrossRef]

241. Pollheimer, J.; Loregger, T.; Sonderegger, S.; Saleh, L.; Bauer, S.; Bilban, M.; Czerwenka, K.; Husslein, P.; Knofler, M. Activation of the canonical wingless/T-cell factor signaling pathway promotes invasive differentiation of human trophoblast. Am. J. Pathol. 2006, 168, 1134-1147. [CrossRef] [PubMed]

242. Knofler, M.; Pollheimer, J. Human placental trophoblast invasion and differentiation: A particular focus on Wnt signaling. Front. Genet. 2013, 4, 190. [CrossRef]

243. Zhang, Z.; Li, H.; Zhang, L.; Jia, L.; Wang, P. Differential expression of beta-catenin and Dickkopf-1 in the third trimester placentas from normal and preeclamptic pregnancies: A comparative study. Reprod. Biol. Endocrinol. 2013, 11, 17. [CrossRef] [PubMed]

244. Wang, X.; Zhang, Z.; Zeng, X.; Wang, J.; Zhang, L.; Song, W.; Shi, Y. Wnt/beta-catenin signaling pathway in severe preeclampsia. J. Mol. Histol. 2018, 49, 317-327. [CrossRef] [PubMed]

245. Yu, X.; Zhang, Y.; Yang, P.; Gao, X.; Wang, Y. Downregulated low-density lipoprotein receptor-related protein 6 induces the maldevelopment of extravillous trophoblast via Wnt/beta-catenin signaling pathway. Mol. Cell. Probes 2019, 44, 21-28. [CrossRef]

246. Zhang, Y.; Pan, X.; Yu, X.; Li, L.; Qu, H.; Li, S. MicroRNA-590-3p inhibits trophoblast-dependent maternal spiral artery remodeling by repressing low-density lipoprotein receptor-related protein 6. Mol. Genet. Genom. Med. 2018, 6, 1124-1133. [CrossRef]

247. Kopan, R. Notch signaling. Cold Spring Harb. Perspect. Biol. 2012, 4. [CrossRef]

248. Zhao, W.X.; Lin, J.H. Notch signaling pathway and human placenta. Int. J. Med. Sci. 2012, 9, 447-452. [CrossRef]

249. Haider, S.; Meinhardt, G.; Saleh, L.; Fiala, C.; Pollheimer, J.; Knofler, M. Notch1 controls development of the extravillous trophoblast lineage in the human placenta. Proc. Natl. Acad. Sci. USA 2016, 113, E7710-E7719. [CrossRef]

250. Cobellis, L.; Mastrogiacomo, A.; Federico, E.; Schettino, M.T.; De Falco, M.; Manente, L.; Coppola, G.; Torella, M.; Colacurci, N.; De Luca, A. Distribution of Notch protein members in normal and preeclampsia-complicated placentas. Cell Tissue Res. 2007, 330, 527-534. [CrossRef]

251. Zhao, W.X.; Huang, T.T.; Jiang, M.; Feng, R.; Lin, J.H. Expression of notch family proteins in placentas from patients with early-onset severe preeclampsia. Reprod. Sci. 2014, 21, 716-723. [CrossRef] [PubMed]

252. Fragkiadaki, P.; Soulitzis, N.; Sifakis, S.; Koutroulakis, D.; Gourvas, V.; Vrachnis, N.; Spandidos, D.A. Downregulation of notch signaling pathway in late preterm and term placentas from pregnancies complicated by preeclampsia. PLoS ONE 2015, 10, e0126163. [CrossRef] [PubMed]

253. Shimanuki, Y.; Mitomi, H.; Fukumura, Y.; Makino, S.; Itakura, A.; Yao, T.; Takeda, S. Alteration of Delta-like ligand 1 and Notch 1 receptor in various placental disorders with special reference to early onset preeclampsia. Hum. Pathol. 2015, 46, 1129-1137. [CrossRef] [PubMed]

254. Liu, J.J.; Zhang, L.; Zhang, F.F.; Luan, T.; Yin, Z.M.; Rui, C.; Ding, H.J. Influence of miR-34a on preeclampsia through the Notch signaling pathway. Eur. Rev. Med. Pharmacol. Sci. 2019, 23, 923-931. [CrossRef] [PubMed]

255. Zhao, W.X.; Wu, Z.M.; Liu, W.; Lin, J.H. Notch2 and Notch3 suppress the proliferation and mediate invasion of trophoblast cell lines. Biol. Open 2017, 6, 1123-1129. [CrossRef] [PubMed]

256. Doridot, L.; Houry, D.; Gaillard, H.; Chelbi, S.T.; Barbaux, S.; Vaiman, D. miR-34a expression, epigenetic regulation, and function in human placental diseases. Epigenetics 2014, 9, 142-151. [CrossRef] [PubMed]

257. Pang, R.T.; Leung, C.O.; Ye, T.M.; Liu, W.; Chiu, P.C.; Lam, K.K.; Lee, K.F.; Yeung, W.S. MicroRNA-34a suppresses invasion through downregulation of Notch1 and Jagged1 in cervical carcinoma and choriocarcinoma cells. Carcinogenesis 2010, 31, 1037-1044. [CrossRef]

258. Barquilla, A.; Pasquale, E.B. Eph receptors and ephrins: Therapeutic opportunities. Annu. Rev. Pharmacol. Toxicol. 2015, 55, 465-487. [CrossRef] 
259. Zeng, X.; Hunt, A.; Jin, S.C.; Duran, D.; Gaillard, J.; Kahle, K.T. EphrinB2-EphB4-RASA1 Signaling in Human Cerebrovascular Development and Disease. Trends Mol. Med. 2019, 25, 265-286. [CrossRef]

260. Dong, H.; Yu, C.; Mu, J.; Zhang, J.; Lin, W. Role of EFNB2/EPHB4 signaling in spiral artery development during pregnancy: An appraisal. Mol. Reprod. Dev. 2016, 83, 12-18. [CrossRef]

261. Liu, X.; Hu, Y.; Zheng, Y.; Liu, X.; Luo, M.; Liu, W.; Zhao, Y.; Zou, L. EPHB4 Regulates Human Trophoblast Cell Line HTR-8/SVneo Function: Implications for the Role of EPHB4 in Preeclampsia. Biol. Reprod. 2016, 95, 65. [CrossRef] [PubMed]

262. Red-Horse, K.; Kapidzic, M.; Zhou, Y.; Feng, K.T.; Singh, H.; Fisher, S.J. EPHB4 regulates chemokine-evoked trophoblast responses: A mechanism for incorporating the human placenta into the maternal circulation. Development 2005, 132, 4097-4106. [CrossRef] [PubMed]

263. Liu, X.; Liu, X.; Liu, W.; Luo, M.; Tao, H.; Wu, D.; Zhao, Y.; Zou, L. HOXA9 transcriptionally regulates the EPHB4 receptor to modulate trophoblast migration and invasion. Placenta 2017, 51, 38-48. [CrossRef] [PubMed]

264. Zhang, Y.; Fei, M.; Xue, G.; Zhou, Q.; Jia, Y.; Li, L.; Xin, H.; Sun, S. Elevated levels of hypoxia-inducible microRNA-210 in pre-eclampsia: New insights into molecular mechanisms for the disease. J. Cell. Mol. Med. 2012, 16, 249-259. [CrossRef] [PubMed]

265. Siddle, K. Signalling by insulin and IGF receptors: Supporting acts and new players. J. Mol. Endocrinol. 2011, 47, R1-R10. [CrossRef] [PubMed]

266. Forbes, K.; Westwood, M.; Baker, P.N.; Aplin, J.D. Insulin-like growth factor I and II regulate the life cycle of trophoblast in the developing human placenta. Am. J. Physiol. Cell Physiol. 2008, 294, C1313-C1322. [CrossRef] [PubMed]

267. Hiden, U.; Glitzner, E.; Hartmann, M.; Desoye, G. Insulin and the IGF system in the human placenta of normal and diabetic pregnancies. J. Anat. 2009, 215, 60-68. [CrossRef]

268. Dubova, E.A.; Pavlov, K.A.; Lyapin, V.M.; Kulikova, G.V.; Shchyogolev, A.I.; Sukhikh, G.T. Expression of insulin-like growth factors in the placenta in preeclampsia. Bull. Exp. Biol. Med. 2014, 157, 103-107. [CrossRef]

269. Nawathe, A.R.; Christian, M.; Kim, S.H.; Johnson, M.; Savvidou, M.D.; Terzidou, V. Insulin-like growth factor axis in pregnancies affected by fetal growth disorders. Clin. Epigenet. 2016, 8, 11. [CrossRef]

270. Cohen, M.; Meisser, A.; Bischof, P. Metalloproteinases and human placental invasiveness. Placenta 2006, 27, 783-793. [CrossRef]

271. Isaka, K.; Usuda, S.; Ito, H.; Sagawa, Y.; Nakamura, H.; Nishi, H.; Suzuki, Y.; Li, Y.F.; Takayama, M. Expression and activity of matrix metalloproteinase 2 and 9 in human trophoblasts. Placenta 2003, 24, 53-64. [CrossRef] [PubMed]

272. Staun-Ram, E.; Goldman, S.; Gabarin, D.; Shalev, E. Expression and importance of matrix metalloproteinase 2 and 9 (MMP-2 and -9) in human trophoblast invasion. Reprod. Biol. Endocrinol. 2004, 2, 59. [CrossRef] [PubMed]

273. Zhu, J.; Zhong, M.; Pang, Z.; Yu, Y. Dysregulated expression of matrix metalloproteinases and their inhibitors may participate in the pathogenesis of pre-eclampsia and fetal growth restriction. Early Hum. Dev. 2014, 90, 657-664. [CrossRef] [PubMed]

274. Plaks, V.; Rinkenberger, J.; Dai, J.; Flannery, M.; Sund, M.; Kanasaki, K.; Ni, W.; Kalluri, R.; Werb, Z. Matrix metalloproteinase-9 deficiency phenocopies features of preeclampsia and intrauterine growth restriction. Proc. Natl. Acad. Sci. USA 2013, 110, 11109-11114. [CrossRef]

275. Jin, M.; Li, H.; Xu, H.; Huo, G.; Yao, Y. MicroRNA-20b inhibits trophoblast cell migration and invasion by targeting MMP-2. Int. J. Clin. Exp. Pathol. 2017, 10, 10901-10909.

276. Yu, Y.; Wang, L.; Liu, T.; Guan, H. MicroRNA-204 suppresses trophoblast-like cell invasion by targeting matrix metalloproteinase-9. Biochem. Biophys. Res. Commun. 2015, 463, 285-291. [CrossRef]

277. Su, M.T.; Tsai, P.Y.; Tsai, H.L.; Chen, Y.C.; Kuo, P.L. miR-346 and miR-582-3p-regulated EG-VEGF expression and trophoblast invasion via matrix metalloproteinases 2 and 9. Biofactors 2017, 43, 210-219. [CrossRef]

278. Zhang, H.; Hou, L.; Li, C.M.; Zhang, W.Y. The chemokine CXCL6 restricts human trophoblast cell migration and invasion by suppressing MMP-2 activity in the first trimester. Hum. Reprod. 2013, 28, 2350-2362. [CrossRef]

279. Xie, L.; Mouillet, J.F.; Chu, T.; Parks, W.T.; Sadovsky, E.; Knofler, M.; Sadovsky, Y. C19MC microRNAs regulate the migration of human trophoblasts. Endocrinology 2014, 155, 4975-4985. [CrossRef] 
280. Wu, D.; Chen, X.; Wang, L.; Chen, F.; Cen, H.; Shi, L. Hypoxia-induced microRNA-141 regulates trophoblast apoptosis, invasion, and vascularization by blocking CXCL12beta/CXCR2/4 signal transduction. Biomed. Pharmacother. 2019, 116, 108836. [CrossRef]

281. Qiu, Q.; Yang, M.; Tsang, B.K.; Gruslin, A. EGF-induced trophoblast secretion of MMP-9 and TIMP-1 involves activation of both PI3K and MAPK signalling pathways. Reproduction 2004, 128, 355-363. [CrossRef] [PubMed]

282. Li, Y.; Klausen, C.; Zhu, H.; Leung, P.C. Activin A Increases Human Trophoblast Invasion by Inducing SNAIL-Mediated MMP2 Up-Regulation Through ALK4. J. Clin. Endocrinol. Metab. 2015, 100, E1415-E1427. [CrossRef] [PubMed]

283. Chen, D.B.; Zheng, J. Regulation of placental angiogenesis. Microcirculation 2014, 21, 15-25. [CrossRef] [PubMed]

284. Lash, G.E.; Cartwright, J.E.; Whitley, G.S.; Trew, A.J.; Baker, P.N. The effects of angiogenic growth factors on extravillous trophoblast invasion and motility. Placenta 1999, 20, 661-667. [CrossRef] [PubMed]

285. Lash, G.E.; Warren, A.Y.; Underwood, S.; Baker, P.N. Vascular endothelial growth factor is a chemoattractant for trophoblast cells. Placenta 2003, 24, 549-556. [CrossRef] [PubMed]

286. Liu, Q.; Yang, J. Expression and significance of miR155 and vascular endothelial growth factor in placenta of rats with preeclampsia. Int. J. Clin. Exp. Med. 2015, 8, 15731-15737. [PubMed]

287. Lyall, F.; Young, A.; Boswell, F.; Kingdom, J.C.; Greer, I.A. Placental expression of vascular endothelial growth factor in placentae from pregnancies complicated by pre-eclampsia and intrauterine growth restriction does not support placental hypoxia at delivery. Placenta 1997, 18, 269-276. [CrossRef]

288. Zhou, Y.; McMaster, M.; Woo, K.; Janatpour, M.; Perry, J.; Karpanen, T.; Alitalo, K.; Damsky, C.; Fisher, S.J. Vascular endothelial growth factor ligands and receptors that regulate human cytotrophoblast survival are dysregulated in severe preeclampsia and hemolysis, elevated liver enzymes, and low platelets syndrome. Am. J. Pathol. 2002, 160, 1405-1423. [CrossRef]

289. Nanaev, A.; Chwalisz, K.; Frank, H.G.; Kohnen, G.; Hegele-Hartung, C.; Kaufmann, P. Physiological dilation of uteroplacental arteries in the guinea pig depends on nitric oxide synthase activity of extravillous trophoblast. Cell Tissue Res. 1995, 282, 407-421. [CrossRef]

290. Martin, D.; Conrad, K.P. Expression of endothelial nitric oxide synthase by extravillous trophoblast cells in the human placenta. Placenta 2000, 21, 23-31. [CrossRef]

291. Cartwright, J.E.; Holden, D.P.; Whitley, G.S. Hepatocyte growth factor regulates human trophoblast motility and invasion: A role for nitric oxide. Br. J. Pharmacol. 1999, 128, 181-189. [CrossRef] [PubMed]

292. Kulandavelu, S.; Whiteley, K.J.; Qu, D.; Mu, J.; Bainbridge, S.A.; Adamson, S.L. Endothelial nitric oxide synthase deficiency reduces uterine blood flow, spiral artery elongation, and placental oxygenation in pregnant mice. Hypertension 2012, 60, 231-238. [CrossRef] [PubMed]

293. Poehlmann, T.G.; Fitzgerald, J.S.; Meissner, A.; Wengenmayer, T.; Schleussner, E.; Friedrich, K.; Markert, U.R. Trophoblast invasion: Tuning through LIF, signalling via Stat3. Placenta 2005, 26, S37-S41. [CrossRef] [PubMed]

294. Meng, H.X.; Xu, L.N.; Jing, G.; Qian, L.; Qi, M.G. MiR-223 promotes trophoblast cell survival and invasion by targeting STAT3 in preeclampsia. Int. J. Clin. Exp. Med. 2017, 10, 6577-6585.

295. Zhu, X.; Yang, Y.; Han, T.; Yin, G.; Gao, P.; Ni, Y.; Su, X.; Liu, Y.; Yao, Y. Suppression of microRNA-18a expression inhibits invasion and promotes apoptosis of human trophoblast cells by targeting the estrogen receptor alpha gene. Mol. Med. Rep. 2015, 12, 2701-2706. [CrossRef]

296. Bonagura, T.W.; Pepe, G.J.; Enders, A.C.; Albrecht, E.D. Suppression of extravillous trophoblast vascular endothelial growth factor expression and uterine spiral artery invasion by estrogen during early baboon pregnancy. Endocrinology 2008, 149, 5078-5087. [CrossRef]

297. Rahl, P.B.; Young, R.A. MYC and transcription elongation. Cold Spring Harb. Perspect. Med. 2014, 4, a020990. [CrossRef]

298. Butt, E.; Raman, D. New Frontiers for the Cytoskeletal Protein LASP1. Front. Oncol. 2018, 8, 391. [CrossRef]

299. Zou, A.X.; Chen, B.; Li, Q.X.; Liang, Y.C. MiR-134 inhibits infiltration of trophoblast cells in placenta of patients with preeclampsia by decreasing ITGB1 expression. Eur. Rev. Med. Pharmacol. Sci. 2018, 22, 2199-2206. [CrossRef]

300. Poidatz, D.; Dos Santos, E.; Brule, A.; De Mazancourt, P.; Dieudonne, M.N. Estrogen-related receptor gamma modulates energy metabolism target genes in human trophoblast. Placenta 2012, 33, 688-695. [CrossRef] 
301. Dai, Y.; Qiu, Z.; Diao, Z.; Shen, L.; Xue, P.; Sun, H.; Hu, Y. MicroRNA-155 inhibits proliferation and migration of human extravillous trophoblast derived HTR-8/SVneo cells via down-regulating cyclin D1. Placenta 2012, 33, 824-829. [CrossRef] [PubMed]

302. Streit, M.; Riccardi, L.; Velasco, P.; Brown, L.F.; Hawighorst, T.; Bornstein, P.; Detmar, M. Thrombospondin-2: A potent endogenous inhibitor of tumor growth and angiogenesis. Proc. Natl. Acad. Sci. USA 1999, 96, 14888-14893. [CrossRef] [PubMed]

303. Naicker, T.; Dorsamy, E.; Ramsuran, D.; Burton, G.J.; Moodley, J. The role of apoptosis on trophoblast cell invasion in the placental bed of normotensive and preeclamptic pregnancies. Hypertens. Pregnancy 2013, 32, 245-256. [CrossRef] [PubMed]

304. Hertig, A.; Liere, P.; Chabbert-Buffet, N.; Fort, J.; Pianos, A.; Eychenne, B.; Cambourg, A.; Schumacher, M.; Berkane, N.; Lefevre, G.; et al. Steroid profiling in preeclamptic women: Evidence for aromatase deficiency. Am. J. Obstet. Gynecol. 2010, 203, e471-e479. [CrossRef] [PubMed]

305. Perez-Sepulveda, A.; Monteiro, L.J.; Dobierzewska, A.; Espana-Perrot, P.P.; Venegas-Araneda, P.; Guzman-Rojas, A.M.; Gonzalez, M.I.; Palominos-Rivera, M.; Irarrazabal, C.E.; Figueroa-Diesel, H.; et al. Placental Aromatase Is Deficient in Placental Ischemia and Preeclampsia. PLoS ONE 2015, 10, e0139682. [CrossRef] [PubMed]

306. Zhu, H.; Huang, L.; He, Z.; Zou, Z.; Luo, Y. Estrogen-related receptor gamma regulates expression of 17beta-hydroxysteroid dehydrogenase type 1 in fetal growth restriction. Placenta 2018, 67, 38-44. [CrossRef]

307. He, M.; Li, F.; Yang, M.; Fan, Y.; Beejadhursing, R.; Xie, Y.; Zhou, Y.; Deng, D. Impairment of BKca channels in human placental chorionic plate arteries is potentially relevant to the development of preeclampsia. Hypertens. Res. 2018, 41, 126-134. [CrossRef]

308. Chang, K.; Xiao, D.; Huang, X.; Longo, L.D.; Zhang, L. Chronic hypoxia increases pressure-dependent myogenic tone of the uterine artery in pregnant sheep: Role of ERK/PKC pathway. Am. J. Physiol. Heart Circ. Physiol. 2009, 296, H1840-H1849. [CrossRef]

309. Wang, K.; Ahmad, S.; Cai, M.; Rennie, J.; Fujisawa, T.; Crispi, F.; Baily, J.; Miller, M.R.; Cudmore, M.; Hadoke, P.W.; et al. Dysregulation of hydrogen sulfide producing enzyme cystathionine gamma-lyase contributes to maternal hypertension and placental abnormalities in preeclampsia. Circulation 2013, 127, 2514-2522. [CrossRef]

310. Hu, X.Q.; Song, R.; Zhang, L. Effect of Oxidative Stress on the Estrogen-NOS-NO-KCa Channel Pathway in Uteroplacental Dysfunction: Its Implication in Pregnancy Complications. Oxid. Med. Cell. Longev. 2019, 2019, 9194269. [CrossRef]

311. Li, F.F.; He, M.Z.; Xie, Y.; Wu, Y.Y.; Yang, M.T.; Fan, Y.; Qiao, F.Y.; Deng, D.R. Involvement of dysregulated IKCa and SKCa channels in preeclampsia. Placenta 2017, 58, 9-16. [CrossRef] [PubMed]

312. Xiao, D.; Bird, I.M.; Magness, R.R.; Longo, L.D.; Zhang, L. Upregulation of eNOS in pregnant ovine uterine arteries by chronic hypoxia. Am. J. Physiol. Heart Circ. Physiol. 2001, 280, H812-H820. [CrossRef] [PubMed]

313. Schiessl, B.; Strasburger, C.; Bidlingmaier, M.; Mylonas, I.; Jeschke, U.; Kainer, F.; Friese, K. Plasma- and urine concentrations of nitrite/nitrate and cyclic Guanosinemonophosphate in intrauterine growth restricted and preeclamptic pregnancies. Arch. Gynecol. Obstet. 2006, 274, 150-154. [CrossRef] [PubMed]

314. Krause, B.J.; Carrasco-Wong, I.; Caniuguir, A.; Carvajal, J.; Farias, M.; Casanello, P. Endothelial eNOS/arginase imbalance contributes to vascular dysfunction in IUGR umbilical and placental vessels. Placenta 2013, 34, 20-28. [CrossRef]

315. Jobe, S.O.; Tyler, C.T.; Magness, R.R. Aberrant synthesis, metabolism, and plasma accumulation of circulating estrogens and estrogen metabolites in preeclampsia implications for vascular dysfunction. Hypertension 2013, 61, 480-487. [CrossRef]

316. Pecks, U.; Rath, W.; Kleine-Eggebrecht, N.; Maass, N.; Voigt, F.; Goecke, T.W.; Mohaupt, M.G.; Escher, G. Maternal Serum Lipid, Estradiol, and Progesterone Levels in Pregnancy, and the Impact of Placental and Hepatic Pathologies. Geburtshilfe Frauenheilkd. 2016, 76, 799-808. [CrossRef]

317. Ouyang, Y.; Mouillet, J.F.; Coyne, C.B.; Sadovsky, Y. Review: Placenta-specific microRNAs in exosomes—Good things come in nano-packages. Placenta 2014, 35, S69-S73. [CrossRef]

318. Cronqvist, T.; Tannetta, D.; Morgelin, M.; Belting, M.; Sargent, I.; Familari, M.; Hansson, S.R. Syncytiotrophoblast derived extracellular vesicles transfer functional placental miRNAs to primary human endothelial cells. Sci. Rep. 2017, 7, 4558. [CrossRef] 
319. Shao, X.; Liu, Y.; Liu, M.; Wang, Y.; Yan, L.; Wang, H.; Ma, L.; Li, Y.X.; Zhao, Y.; Wang, Y.L. Testosterone Represses Estrogen Signaling by Upregulating miR-22: A Mechanism for Imbalanced Steroid Hormone Production in Preeclampsia. Hypertension 2017, 69, 721-730. [CrossRef]

320. Berkane, N.; Liere, P.; Lefevre, G.; Alfaidy, N.; Nahed, R.A.; Vincent, J.; Oudinet, J.P.; Pianos, A.; Cambourg, A.; Rozenberg, P.; et al. Abnormal steroidogenesis and aromatase activity in preeclampsia. Placenta 2018, 69, 40-49. [CrossRef]

321. Hu, X.Q.; Dasgupta, C.; Chen, M.; Xiao, D.; Huang, X.; Han, L.; Yang, S.; Xu, Z.; Zhang, L. Pregnancy Reprograms Large-Conductance $\mathrm{Ca}^{2+}$-Activated $\mathrm{K}^{+}$Channel in Uterine Arteries: Roles of Ten-Eleven Translocation Methylcytosine Dioxygenase 1-Mediated Active Demethylation. Hypertension 2017, 69, 1181-1191. [CrossRef] [PubMed]

322. Dasgupta, C.; Chen, M.; Zhang, H.; Yang, S.; Zhang, L. Chronic hypoxia during gestation causes epigenetic repression of the estrogen receptor-alpha gene in ovine uterine arteries via heightened promoter methylation. Hypertension 2012, 60, 697-704. [CrossRef] [PubMed]

323. Park, M.N.; Park, K.H.; Lee, J.E.; Shin, Y.Y.; An, S.M.; Kang, S.S.; Cho, W.S.; An, B.S.; Kim, S.C. The expression and activation of sex steroid receptors in the preeclamptic placenta. Int. J. Mol. Med. 2018, 41, 2943-2951. [CrossRef]

324. Babicheva, A.; Ayon, R.J.; Makino, A.; Yuan, J.X.J. Increased expression of microRNA-29b attenuates function of $\mathrm{Ca}^{2+}$-activated $\mathrm{K}^{+}$channels in human PASMC from idiopathic PAH patients. FASEB J. 2018, 32, lb1-lb925.

325. Tu, J.; Ng, S.H.; Luk, A.C.; Liao, J.; Jiang, X.; Feng, B.; Lun Mak, K.K.; Rennert, O.M.; Chan, W.Y.; Lee, T.L. MicroRNA-29b/Tet1 regulatory axis epigenetically modulates mesendoderm differentiation in mouse embryonic stem cells. Nucleic Acids Res. 2015, 43, 7805-7822. [CrossRef]

326. Yang, G.; Pei, Y.; Cao, Q.; Wang, R. MicroRNA-21 represses human cystathionine gamma-lyase expression by targeting at specificity protein-1 in smooth muscle cells. J. Cell. Physiol. 2012, 227, 3192-3200. [CrossRef]

327. Lasabova, Z.; Vazan, M.; Zibolenova, J.; Svecova, I. Overexpression of miR-21 and miR-122 in preeclamptic placentas. Neuroendocrinol. Lett. 2015, 36, 695-699.

(C) 2019 by the authors. Licensee MDPI, Basel, Switzerland. This article is an open access article distributed under the terms and conditions of the Creative Commons Attribution (CC BY) license (http://creativecommons.org/licenses/by/4.0/). 